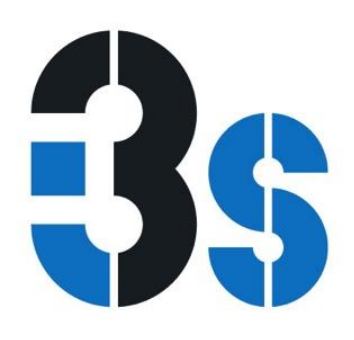

\title{
Serotonergic mechanisms of trigeminal meningeal nociception: Implications for migraine pain
}

\author{
Erkan Kilin, Cindy Guerrero-Toro, Andrey Zakharov, \\ Carmela Vitale, Max Gubert-Olive, Ksenia Koroleva, \\ Arina Timonina, Liliana L. Luz, Irina Shelukhina, \\ Raisa Giniatullina, Fatma Tore, Boris V. Safronov, \\ Rashid Giniatullin
}

Originally published in Neuropharmacology 116 (2017) 160-173.

\begin{abstract}
Serotonergic mechanisms play a central role in migraine pathology. However, the regionspecific effects of serotonin (5-HT) mediated via multiple types of receptors in the nociceptive system are poorly understood. Using extracellular and patch-clamp recordings, we studied the action of 5-HT on the excitability of peripheral and central terminals of trigeminal afferents. 5-HT evoked long-lasting TTX-sensitive firing in the peripheral terminals of meningeal afferents, the origin site of migraine pain. Cluster analysis revealed that in majority of nociceptive fibers $5-\mathrm{HT}$ induced either transient or persistent spiking activity with prevailing delta and theta rhythms. The 5-HT3-receptor antagonist MDL-72222 or 5-HT1B/D-receptor antagonist GR127935 largely reduced, but their combination completely prevented the excitatory pro-nociceptive action of 5-HT. The 5HT3 agonist mCPBG activated spikes in MDL-72222-dependent manner but the 5HT-1 receptor agonist sumatriptan did not affect the nociceptive firing. 5-HT also triggered peripheral CGRP release in meninges, which was blocked by MDL-72222.5-HT evoked fast membrane currents and $\mathrm{Ca}^{+}$transients in a fraction of trigeminal neurons. Immunohistochemistry showed expression of $5-\mathrm{HT} 3 \mathrm{~A}$ receptors in fibers innervating meninges. Endogenous release of 5-HT from degranulated mast cells increased nociceptive firing. Low pH but not histamine strongly activated firing. 5-HT reduced monosynaptic inputs from trigeminal $\mathrm{A} \delta$ - and $\mathrm{C}$-afferents to the upper cervical lamina I neurons and this effect was blocked by MDL-72222. Consistent with central inhibitory effect, 5 -HT reduced CGRP release in the brainstem slices. In conclusion, 5-HT evokes powerful pro-nociceptive peripheral and anti-nociceptive central effects in trigeminal system transmitting migraine pain.
\end{abstract}




\section{INTRODUCTION}

Migraine is a common neurological disorder which pathophysiology is still poorly understood. For decades, serotonergic mechanisms were supposed to play a key role in migraine pathology (Lance et al., 1967; Dussor, 2014; Hamel, 2007). During migraine attacks, the plasma level of serotonin $(5-\mathrm{HT})$ raises dramatically, whereas between attacks it goes down (Ferrari et al., 1989). Early studies reported the ability of 5-HT to inhibit migraine attack (Lance et al., 1967). In general, a low 5-HT level combined with high receptor sensitivity has been proposed as a factor increasing the risk of migraine (Panconesi, 2008). However, because of a wide range of receptors for 5-HT and its regionspecific effects on the nociceptive system (Saxena and Ferrari, 1992; Viguier et al., 2013), there are a number of contradictory reports on the role of $5-\mathrm{HT}$ in migraine (CervantesDurán et al., 2013; Hamel, 2007).

The 5-HT-caused pain is mediated, at least in part, via activation of perivascular nociceptive fibers innervating extracranial arteries (Koo and Balaban, 2006). 5-HT also has pro-nociceptive action when applied to the dura mater as a component of the inflammatory soup (Strassman et al., 1996; Lukács et al., 2015; Oshinsky and Gomonchareonsiri, 2007). However, the mechanism of the 5-HT-induced pro-nociceptive effect at trigeminal nerve terminals in the meninges remains poorly understood. For example, sumatriptan, one of the most specific anti-migraine agents, is an agonist of the 5- HT1B and 5-HT1D receptors but the site of its action within the nociceptive system still remains to be elucidated (Dussor, 2014). The 5-HT1B receptor is located on vascular smooth muscles and the 5-HT1D receptor on the peripheral and central terminals of the dural afferents (Harriott et al., 2012). Thus, it is reasonable to suggest that both peripheral and central sites represent potential targets for anti-migraine therapy by triptans (Goadsby and Hoskin, 1998; Donaldson et al., 2002). Indeed, Amrutkar et al. (2012) found that sumatriptan inhibited CGRP release both in dura mater and in the brainstem.

The meninges comprising pia and dura mater play one of the major roles in the generation of migraine headaches (Goadsby and Edvinsson, 1993; Strassman et al., 1996; Olesen et al., 2009; Zakharov et al., 2015). Stimulation of the trigeminal ganglia induced release of the migraine mediator CGRP into cranial circulation and this effect was blocked by sumatriptan (Goadsby and Edvinsson, 1993). Many key studies were performed in animal migraine models in vivo when meninges were stimulated after sensitization induced by inflammatory compounds and recordings were made either from trigeminal ganglion or from brainstem (Strassman et al., 1996; Goadsby and Hoskin, 1998; Burstein et al., 2005). Meninges have a large number of $5-\mathrm{HT}$-containing mast cells considered as one of the migraine triggers (Levy, 2009). Degranulation of mast cells in vivo induces a long-lasting activation of meningeal nociceptors (Levy et al., 2007). Platelets containing 5- HT in their dense-body granules have also been suggested to contribute to some forms of migraine (Taffi et al., 2005; Borgdorff and Tangelder, 2012; Danese et al., 2014).

The 5-HT3 receptor, the only ionotropic receptor in the extended 5-HT receptor family, mediates excitatory responses in the central and peripheral sensory neurons (CervantesDurán et al., 2013; Hicks et al., 2002). There are contradictory data on the functional role of 5 -HT3 receptors in the spinal cord, as both pro- and anti-nociceptive effects were reported (Green et al., 2000; Kim et al., 2015; Oatway et al., 2004). About 20\% of 
descending serotonergic terminals make axo-axonal contacts with primary afferents (Zhang et al., 2015), implying their involvement in the presynaptic control of peripheral inputs. In agreement with the pro-nociceptive action of 5-HT, 5-HT3 receptor antagonists are commonly used for pain therapy (Greenshaw and Silverstone, 1997; Sagalajev et al., 2015). However, their mechanisms of action have not been studied in a migraine pain models, which may have its specific physiological properties and neurochemical profile.

Recently, we developed a novel cluster approach to analyze nociceptive discharges in isolated trigeminal fibers innervating cranial meninges, the origin site of migraine pain (Zakharov et al., 2015). This technique overcomes several limitations of the in vivo experiments: one can directly record activity in nociceptive terminals under conditions of adequate drug concentration control and without application of concomitant anesthesia.

In the present study, we show that the robust activation of the peripheral nerve terminals by 5 - HT is opposed by its inhibitory action on the central terminals, and that both these effects are mediated via the same $5-\mathrm{HT} 3$ receptor.

\section{MATERIALS AND METHODS}

\section{Preparations}

Experiments were performed in accordance with the European Community Council Directive of September 22, 2010 (2010/63/ EEC). Wistar rats from the Animal House of the University of Eastern Finland were housed in cages with controlled temperature, humidity and 12-h light-dark cycle. Food and water were served ad libitum. The protocols were approved by the Animal Care and Use Committee of the University of Eastern Finland. The isolated rat hemiskulls were prepared from adult (5 weeks) male rats as described previously (Zakharov et al., 2015). Briefly, the rats were decapitated after $\mathrm{CO}_{2}$ inhalation, the skin and muscles were removed from the skull, which was divided into halves by a cut along the sagittal suture. The brain hemispheres were removed without harming the trigeminal ganglia and the meningeal dura mater.

For the whole-cell recordings, laboratory Wistar rats of both sexes (P15-18) were killed by decapitation in accordance with the Portuguese guidelines (Direcção Geral de Alimentação e Veterinária, Ministério da Agricultura) after anesthesia with intraperitoneal injection of $\mathrm{Na}^{+}$-pentobarbital $(30 \mathrm{mg} / \mathrm{kg}$ ) and a subsequent check for a lack of pedal withdrawal reflexes. The experiments were carried out according to the guidelines laid down by the institution's animal welfare committee (Comissão de Ética do Instituto de Biologia Molecular e Celular). The trigeminospinal complex (the brainstem and the upper cervical spinal cord) with the trigeminal nerve attached was quickly isolated in oxygenated artificial cerebrospinal fluid (ACSF) containing (in $\mathrm{mM}$ ): $\mathrm{NaCl} 115, \mathrm{KCl} 3, \mathrm{CaCl}_{2} 2, \mathrm{MgCl}_{2} 1$, $\mathrm{NaH}_{2} \mathrm{PO}_{4}$ 1, $\mathrm{NaHCO}_{3} 25$ and glucose 11; (bubbled with 95\% 02/5\% CO2) at room temperature. The pia mater in the spinal segments $\mathrm{C} 1-\mathrm{C} 2$ was locally removed with forceps and scissors, to provide access for the recording pipettes. The isolated trigeminospinal complex was glued with cyanoacrylate adhesive to a plate made of gold (the dorsolateral surface was up) and transferred to the recording chamber. Lamina I neurons in the C1-C2 segment were visualized through the intact white matter using the 
oblique infrared light-emitting-diode illumination technique (Safronov et al., 2007; Szucs et al., 2009).

Primary cell cultures of trigeminal ganglia of Wistar male rats (P10-12, Animal Center of the University of Eastern Finland, Kuopio, Finland) were prepared as described previously (Fabbretti et al., 2006). In brief, trigeminal ganglia were isolated and ganglion cells dissociated using an enzyme cocktail containing trypsin $(0.25 \mathrm{mg} / \mathrm{mL})$ and collagenase type I $(760 \mathrm{U} / \mathrm{mL})$ under continuous shaking $(850 \mathrm{rpm})$ at $37^{\circ} \mathrm{C}$ for $15 \mathrm{~min}$. Cells were plated on coverslips coated with poly-L-lysine $(0.2 \mathrm{mg} / \mathrm{ml}$, P1399, Sigma-Aldrich Co. St. Louis, MO USA) and cultured in F12 medium supplemented with FBS 10\% (10270-106; Gibco Invitrogen, Carlsbad, $\mathrm{CA}, \mathrm{USA})$ at $37{ }^{\circ} \mathrm{C}$ in an atmosphere saturated with $5 \% \mathrm{CO}_{2}$ for $48 \mathrm{~h}$ prior to $\mathrm{Ca}^{2+}$ imaging.

\section{Electrophysiology}

The hemiskull preparation obtained from Wistar rats was used for the suction electrode recording of activity in the nervus spinosus, which is a part of the mandibular branch of the trigeminal nerve (Schueler et al., 2013). The recording was carried out with a DAM80i amplifier (band pass $0.1-1000 \mathrm{~Hz}$, gain 10,000) using fire- polished glass microelectrodes with a tip diameter of $\sim 150 \mu \mathrm{m}$ filled with ACSF. Spontaneous and drug-induced action potentials generated in the distal parts of the transected nervus spinosus were recorded at a room temperature of $20-22{ }^{\circ} \mathrm{C}$. We waited for stabilization of the baseline conditions for at least $15 \mathrm{~min}$. Recordings of meningeal spikes in control $(20 \mathrm{~min})$ were followed by those in the presence of 5-HT or its agonists. Each concentration of the 5-HT agonists was tested in a new hemiskull preparation. All spikes were visually inspected to prevent inclusion of non-specific signals. All traces were digitized at $8 \mu$ sec intervals using a NIPCI6221 data acquisition board (National Instruments, Austin, TX, USA) with WinEDR software (Strathclyde University, UK) and stored on a PC for off-line analysis.

Whole-cell recordings from lamina I neurons in the isolated trigeminospinal complex were done using the method described elsewhere (Pinto et al., 2010; Szucs et al., 2009). The pipettes were pulled from thick-walled glass (BioMedical Instruments, Zöllnitz, Germany)

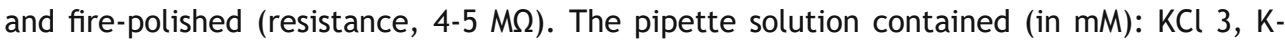
gluconate $150, \mathrm{MgCl}_{2} 1$, BAPTA 1 , and HEPES $10\left(\mathrm{pH}=7.3\right.$ adjusted with $\mathrm{KOH}$, final [ $\left.\mathrm{K}^{+}\right]$was $160 \mathrm{mM}$ ). The amplifier was an EPC10-Double (HEKA, Lambrecht, Germany).

The signal was low-pass filtered at $2.9 \mathrm{kHz}$ and sampled at $10 \mathrm{kHz}$. Offset potentials were compensated before seal formation. Liquid junction potentials were calculated and corrected using the compensation circuitry of the amplifier.

Primary afferent inputs were evoked by stimulating the trigeminal nerve via suction electrode as described in Pinto et al.(2010) using an isolated pulse stimulator (2100, A-M Systems, Sequim, WA, USA). A $50 \mu$ s pulse $(600-850 \mu A)$ was applied to activate Aठ fibers and a $1 \mathrm{~ms}$ pulse $(600-850 \mu \mathrm{A})$ to activate both $A \delta$ and $\mathrm{C}$ fibers. Monosynaptic excitatory postsynaptic currents (EPSCS) were identified on the basis of low failure rates and small latency variations as described previously (Pinto et al., 2010). The afferent conduction velocity $(\mathrm{CV})$ was calculated by dividing the conduction distance by the conduction time. The former included the length of the trigeminal nerve from the opening of the suction electrode to its entry zone and the estimated pathway within the brainstem and spinal 
cord. The pathway was measured from video images and calculated as the sum of the rostrocaudal and mediolateral distances between the cell body and the trigeminal nerve entry zone. The A $\delta$-fiber EPSCs were identified as those evoked by $50 \mu$ stimulations and showing the afferent CV between $1.51 \mathrm{~m} / \mathrm{s}$ and $0.7 \mathrm{~m} / \mathrm{s}$; the C-fiber EPSCs were evoked by $1 \mathrm{~ms}$ stimulations and their afferent $\mathrm{CV}$ was lower than $0.7 \mathrm{~m} / \mathrm{s}$. All measurements were done at $22-24 \stackrel{\circ}{\circ}$.

Whole-cell patch clamp recordings from isolated trigeminal neurons were performed as described previously (Hautaniemi et al., 2012; Zakharov et al., 2015) using the PC-10 amplifier (HEKA Elektronik). Microelectrodes (4-5 MS) were filled with intracellular solution containing (in $\mathrm{mM}$ ): $130 \mathrm{CsCl}, 10 \mathrm{HEPES}, 5 \mathrm{EGTA}, 0.5 \mathrm{CaCl}_{2}, 5 \mathrm{MgCl}_{2}, 5 \mathrm{KATP}, 0.5$ NaGTP. The extracellular solution contained (in $\mathrm{mM}$ ): $152 \mathrm{NaCl}, 5 \mathrm{KCl}, 1 \mathrm{MgCl}_{2}, 2 \mathrm{CaCl}_{2}, 10$ glucose and 10 HEPES ( $\mathrm{pH}$ adjusted to 7.4 with $\mathrm{NaOH}$ ). Holding potential of neurons was 70 $\mathrm{mV}$. 5-HT and mCPBG were applied through a rapid superfusion system (RSC-200; BioLogic, Grenoble, France). The data were analyzed using the software FitMaster (HEKA Elektronik).

\section{Off-line cluster analysis of spikes}

Acquisition of signals from the meningeal afferents and cluster analysis were carried out as described previously (Zakharov et al., 2015). All spikes considered in this study had amplitudes exceeding the level of five $\sigma$ (standard deviation) of the background noise. The amplitude of each spike is expressed in the $\sigma$ values (arbitrary units, a.u.). Amplitudes and durations of the positive and negative waves of extracellular spikes were used for the cluster separations. The analysis was performed with the MATLAB software (MathWorks, USA) and the KlustaKwik application (Kadir et al., 2014) was used for the spike cluster identification.

\section{CGRP level determination}

Measurement of the CGRP levels was performed with enzyme immunoassays kits (EIA kits, SPIbio, Montigny Le Bretonneux, France) and the samples obtained from hemiskulls were collected as described previously (Ebersberger et al., 1999; Gupta et al., 2010). Each hemiskull with an intact dura mater was perfused for $30 \mathrm{~min}$ with ACSF at a room temperature. Then the hemiskulls were placed into Vaseline-filled chambers and the cavities were washed 3 times with $350 \mathrm{~mL}$ of ACSF for $15 \mathrm{~min}$ for stabilization and refilled with fresh ACSF. After the third stabilization/washing step the hemiskulls were refilled with the test compound solution in ACSF. After a 15 min incubation period, the liquid samples $(250 \mu \mathrm{l})$ were collected after $15 \mathrm{~min}$ exposure to the testing compounds dissolved in ACSF by gentle pipetting without touching the dura mater. Samples then were put into the test tubes with EIA buffer containing the peptidase inhibitors. The tubes were immediately placed in liquid nitrogen. This protocol was carried out in duplicates. The rest of the assay protocol was carried out according to the manufacturer's instructions. Briefly, after wells were rinsed with the wash buffer, $100 \mu \mathrm{L}$ of sample or CGRP standard were added into the relevant wells followed by the addition of $100 \mu \mathrm{L}$ of anti-CGRP AChE tracer. The 96 -well plates were incubated for the reaction at $4{ }^{\circ} \mathrm{C}$ for $16-20 \mathrm{~h}$ and $200 \mu \mathrm{L}$ 
of Ellman's reagent was added after removal of the supernatant. Brainstem slices were prepared from P10-12 rats as described previously (Kageneck et al., 2014; Wild et al., 2015). Thus, the medullary brainstem was dissected and serial transverse slices $(400 \mu \mathrm{m})$ were cut on a vibrotome (Campden instruments, Switzerland) in ice-cold ACSF. Two brainstem slices from each rat were transferred into a separate well of the 96 wells plate, supplemented with $125 \mu \mathrm{l}$ of ACSF and kept at $37{ }^{\circ} \mathrm{C}$ for $30 \mathrm{~min}$. Then $100 \mu \mathrm{l}$ of ACSF were taken to determine the basic level of CGRP. Next, either $100 \mu \mathrm{l}$ of ACSF (control) or $100 \mu \mathrm{l}$ of $20 \mathrm{mM} 5$-HT containing ACSF were added to different wells. After $15 \mathrm{~min} 100 \mu \mathrm{l}$ samples from each well were taken to determine CGRP levels. Samples were tested in duplicate by using CGRP-EIA kit. Optical density of the wells was measured at $405 \mathrm{~nm}$ using an ELISA reader (microplate photometer, Wallac VICTOR2 ${ }^{\mathrm{T}}$, PerkinElmer, Waltham, Massachusetts, USA). The calibration curve was obtained by using standards with defined CGRP concentrations.

\section{Histochemistry}

The isolated hemiskulls of male P34-36 Wistar rats were fixed in 4\% paraformaldehyde for $2 \mathrm{~h}$, then the dura mater was carefully dissected and post-fixed for $3 \mathrm{~h}$ in the same fixative. The tissue was intensively washed with PBS, pH 7.4 three times for $15 \mathrm{~min}$, and then incubated for $1 \mathrm{~h}$ with PBS containing 10\% normal goat serum (NGS, Jackson Immunores. Lab. Inc., West Grove, PA, USA), 2\% BSA and 0.5\% Tween 20, Sigma, Munich, Germany) for permeabilization and to block unspecific protein binding. A mixture of primary antibodies (rabbit anti-5HT3 3A, Cat. number ASR-031, Alomone Labs, Jerusalem, Israel, and mouse anti-neurofilament light chain, Invitrogen, Carlsbad, California, USA) diluted 1:300 in a buffer was added to the dura mater preparations. After overnight incubation at $4{ }^{\circ} \mathrm{C}$ the samples were washed 3 times for $1 \mathrm{~h}$ with the same buffer, and finally with the permeabilizing solution (1\% NGS, $2 \%$ BSA, $0.5 \%$ Tween 20 in PBS, pH 7.4) for $1 \mathrm{~h}$. Secondary antibodies such as donkey anti-rabbit lgG, Alexa Fluor 488-conjugated (Invitrogen, Carlsbad, California, USA) at a dilution of 1:1000 and the goat anti-mouse IgG, biotin conjugated (Jackson Immunores. Lab. Inc., West Grove, PA, USA) at a dilution of 1:200, were added to the samples for $3 \mathrm{~h}$. After the intensive wash, the dura mater samples were incubated with AMCA-conjugated streptavidin (Jackson Immunores. Lab. Inc., USA) for $1 \mathrm{~h}$, washed, and cover slipped with an aqua mount medium (Sigma, Munich, Germany). The labelling was evaluated by epifluorescence microscopy (Olympus IX70, Tokyo, Japan) using appropriate filter combinations. Controls with secondary antibodies omitted, or pre-incubation of primary antibodies with molar excess of a corresponding peptide 5HT3A (342-355; ASR-031, Alomone Labs.) were processed simultaneously and gave negative results.

For visualization of mast cells, dura maters were detached from the skull and perfused with oxygenated ACSF for $10 \mathrm{~min}$ for stabilization. Then dura samples were exposed to the compound $48 / 80(10 \mu \mathrm{g} / \mathrm{ml})$ for ten minutes, and then fixed with $4 \%$ paraformaldehyde in PBS overnight. Whole-mount preparations were stained with toluidine blue $(\mathrm{pH}: 2.5)$ for observation of mast cells under the stage of the Olympus microscope AX 70. 


\section{Ca $^{2+}$ imaging}

To study the response of cultured trigeminal ganglion cells to $5-\mathrm{HT}$ and capsaicin, intracellular $\mathrm{Ca}^{2+}$ transients were measured. Cells were loaded with the $\mathrm{Ca}^{2+}$ sensitive fluorescent dye Fluo-3 AM (5 $\mu$ M, F1242, Life technologies) in F12 medium supplemented with FBS 10\% (10270-106; Gibco Invitrogen, Carlsbad, California, USA) for 45 min at $37{ }^{\circ} \mathrm{C}$. Then cells were washed out for $15 \mathrm{~min}$ with a BSS and transferred to a chamber continuously perfused with a basic solution. Images were acquired using a microscope imaging setup (TILL Photonics $\mathrm{GmbH}$, Munich, Germany) with a monochromatic light source (excitation $488 \mathrm{~nm}$ ) and the emitted fluorescence was monitored using the respective filters and a 12-bit CCD camera (SensiCam, Kelheim, Germany). 5-HT (20 $\mu \mathrm{M}$, $20 \mathrm{~s})$ and capsaicin ( $1 \mu \mathrm{M}, 2 \mathrm{~s}$ ) were applied via a fast perfusion system (Rapid Solution Changer RSC-200, BioLogic Science Instruments, Grenoble, France), followed by the application of the $50 \mathrm{mM}-\mathrm{KCl}$-containing solution to differentiate neurons from glia (Simonetti et al., 2006). Data were analyzed off-line using TILL Photonics and Origin (MicroCal, Northampton, MA, USA) software.

\section{Statistical analysis}

The paired two-sided Wilcoxon rank sum test or t-test for paired samples was performed to assess the discrepancy of parameters calculated under different conditions in the same preparation, and the unpaired Wilcoxon test or t-test was used for comparing different preparations. The level of significance was set at 0.05. Statistical treatments of the data were carried out using Statistics toolbox (MATLAB) or Origin software. Averaged values are presented as mean \pm SEM.

\section{THEORY}

Migraine pain originates from the peripheral branches of the trigeminal nerve supplying meninges. To be able to 'treat pain at the source', we have to better understand early steps in activation of peripheral meningeal afferents. Until now, functional studies of the peripheral pain traffic were mainly focused on in vivo recordings from higher nociceptiveprocessing centers and had several limitations, i.e. effects of surgery and anesthesia, poor control of applied drug concentration and contamination by activity of local neuronal networks at the site of recording. Although serotonin (5-HT) is widely accepted as a contributor to migraine pathology, reports on the mechanisms of its action are very contradictory due to expression of multiple types of 5-HT receptors in the nociceptive system. We have recently developed the cluster analysis of nociceptive spikes recorded from trigeminal nerve terminals in the isolated dura mater preparation. Here, we used this approach to study in details the complex effect of 5-HT on excitation in different parts of trigeminal primary afferents. We report a dual (pro- and anti-nociceptive) role of 5-HT in peripheral sensory traffic and present the neuropharmacology of these effects. This study improves our understanding of basic principles of nociceptive signaling and opens new perspectives for selective treatment of migraine pain at different levels of the nociceptive system. 


\section{RESULTS}

\section{Long-lasting activation of peripheral nerve terminals by 5-HT}

To study the effect of $5-\mathrm{HT}$ on excitability of the peripheral trigeminal nerve terminals, we performed the suction electrode recordings from the $\mathrm{n}$. spinosus in the hemiskull preparation. Spontaneous discharges in this meningeal nerve in control were compared with those observed in the presence of 5-HT. Application of 5-HT ( $20 \mu \mathrm{M}$ for $10 \mathrm{~min}$ ) induced a robust firing in the trigeminal nerve branches (Fig. 1A). A characteristic feature of the firing evoked by $5-\mathrm{HT}$ was its persistence (Fig. $1 \mathrm{~A}$ and $\mathrm{B}$ ). Thus, despite a very fast removal of the free agonist under our experimental conditions, perfusions lasting as long as 20-30 min were required to restore firing frequencies seen in control. The lowest $5-\mathrm{HT}$ concentration tested $(0.2 \mu \mathrm{M})$ insignificantly increased the global firing in the trigeminal nerve terminals (to $219 \pm 95 \%, p=0.38, n=4$; Fig. $1 C$ ). However, a strong enhancement of firing was seen in 2, 20 or $100 \mu \mathrm{M} 5-\mathrm{HT}$ (increase to $571 \pm 228 \%, \mathrm{p}=0.031, \mathrm{n}=6 ; 683 \pm 139 \%$, $\mathrm{p}=0.0009, \mathrm{n}=11 ; 331 \pm 85 \%, \mathrm{p}=0.001, \mathrm{n}=13$, respectively). Fig. $1 \mathrm{C}$ shows changes in the spiking frequency observed in different $5-\mathrm{HT}$ concentrations, which are presented as a ratio of multiple unit activity (MUA) counts in 5-HT (during 5-10 min) and control (during last 5 min prior 5-HT application). Thus, 5-HT applied to peripheral sites evoked large and persistent activity of the trigeminal nerve terminals.

\section{Variable responses of spike clusters to 5-HT}

Cluster spike analysis (Zakharov et al., 2015) was applied to study the 5-HT effect on individual fibers or small groups of fibers in the nervus spinosus. Plotting the spike amplitude versus duration revealed distinct spike clusters. Each cluster represents a single fiber or small group of nerve fibers of the same type in the trigeminal nerve (Zakharov et al., 2015). Fig. 2A and B shows analysis of three clusters identified in the same nerve which, however, responded differently to the 5-HT application. Essential number of clusters $(71 \%, 231$ of total 327 clusters detected in 34 preparations) increased their firing (responders), while others either reduced firing (13\%, 42 clusters, suppressed) or did not show alterations in their firing behavior (16\%, 54 clusters, non-responders).

More than half of the clusters (53\%) were already activated at the lowest 5-HT concentration tested $(0.2 \mu \mathrm{M}$, Fig. $2 \mathrm{C})$, at which no significant effect on the overall nerve activity was observed. The fraction of responders grew with 5-HT concentration reaching its maximum at $2-20 \mu \mathrm{M}(72-73 \%$, Fig. $2 \mathrm{C})$. It should be noted that the number of responders was higher than the number of suppressed clusters (Fig. $2 C$ and D) being in agreement with the overall pro-nociceptive effect of 5-HT in the whole nerve.

It should be noted that we did not observe 5-HT-induced changes in the amplitude and duration of individual spikes in each cluster (Fig. 2E, shown for the responders). The only parameter which changed in the presence of 5-HT was the discharge frequency (Fig. 2C and D).

To get insight into the origin of the long-lasting effects of 5 -HT on the whole nerve (Fig. $1 \mathrm{~A}$ and $\mathrm{C})$, we studied the time course of the response of individual clusters. In a population of responders, most clusters $(60-70 \%)$ showed a prolonged increase in firing exceeding the period of the drug application (persistent clusters), whereas the remaining 
clusters responded transiently (transient clusters) (Fig. 3A). The fraction of the persistent clusters increased with 5-HT concentrations (Fig. 3B) in consistency with the induction of the long-lasting overall activity observed in the whole nerve (Fig. $1 \mathrm{~A}$ and $\mathrm{C}$ ).

Thus, the clustering approach revealed that single fibers in the trigeminal nerve innervating cranial meninges represent a heterogeneous population in relation to their responses to 5-HT application.

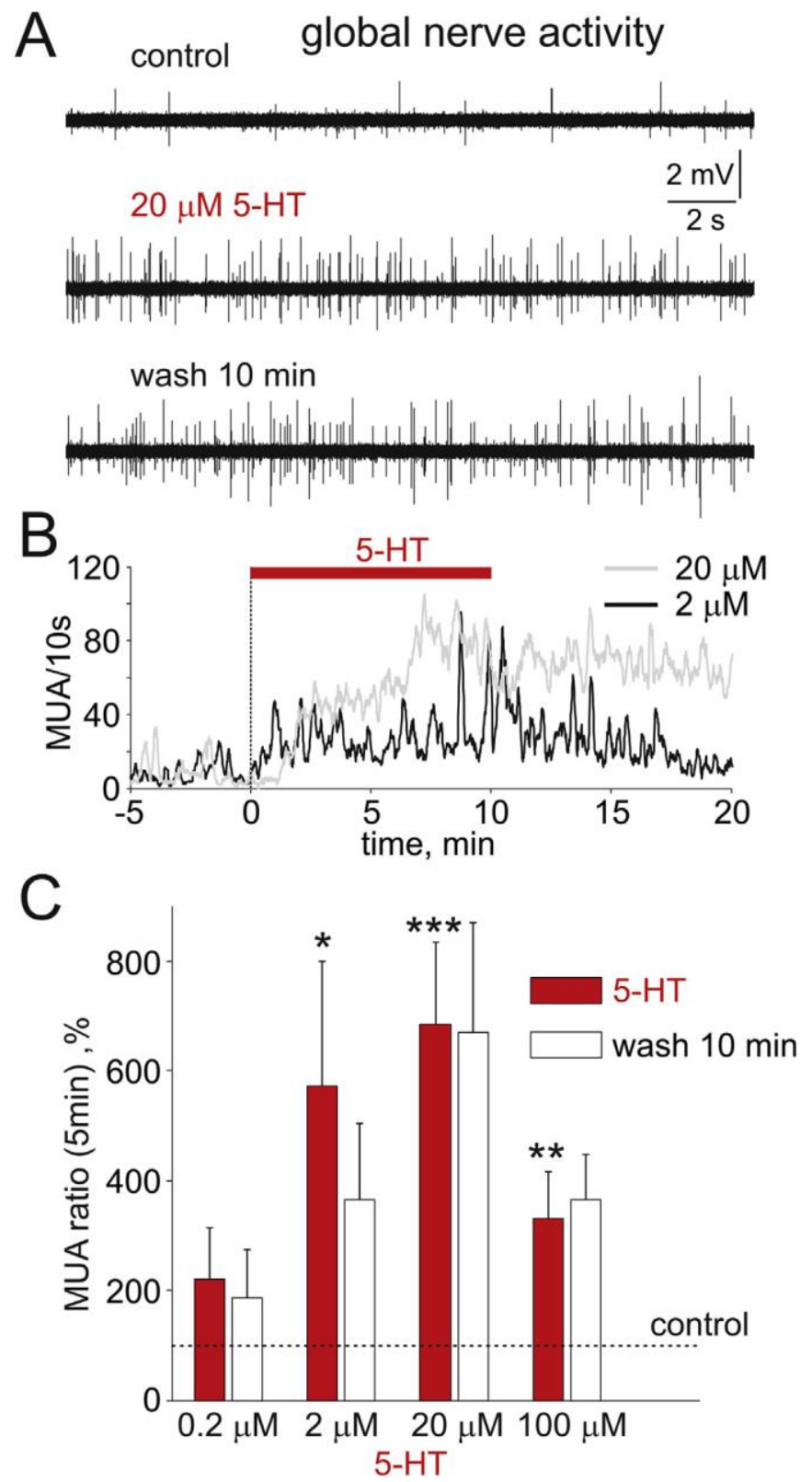

Fig. 1. 5-HT induced nociceptive firing in a meningeal nerve.

(A) Extracellular spikes recorded in the trigeminal nerve innervating meninges in a hemiskull preparation (control, in $20 \mu \mathrm{M} 5-\mathrm{HT}$ and washout). Note the robust firing activated by $5-\mathrm{HT}$.

(B) The time course of spikes activated by 2 and $20 \mu \mathrm{M} 5-\mathrm{HT}$. Firing is presented as multiple unit activity (MUA). Notice the persistence of firing during washout. 
(C) Histograms showing the number of spikes recorded after the application of $0.2,2,20$ and $100 \mu \mathrm{M} 5-\mathrm{HT}$ and during the $10 \mathrm{~min}$ washout period. The numbers of preparatios are: $4,6,11$ and 13 , respectively. $*, p<0.05 ; * *, p$ $<0.01 ; * * *, p<0.001$

\title{
Neurochemical profile of meningeal fibers
}

The cluster approach was further used to describe the neurochemical profile of meningeal fibers. Some clusters (Fig. 4Aa) responded to $5-\mathrm{HT}$, to the algogen ATP $(100 \mu \mathrm{M})$ and to the TRPV1 agonist capsaicin $(1 \mu \mathrm{M})$. However, there were clusters which responded only to 5HT and ATP (Fig. 4Ab) or only to capsaicin (Fig. 4AC). Thus, afferents of the nervus spinosus showed a highly heterogeneous profile of chemical sensitivity (Fig. 4B, summary of 54 clusters). In a total population, $15 \%$ of clusters were co-activated by 5 -HT, ATP and capsaicin, $7 \%$ by $5-\mathrm{HT}$ and ATP, and $31 \%$ by $5-\mathrm{HT}$ and capsaicin. In $11 \%$ of cases, the terminals were purely responsive to $5-\mathrm{HT}$.

We also tested the sensitivity of spikes elicited by $5-\mathrm{HT}$ to the $\mathrm{Na}^{+}$channel blocker TTX (1 $\mu \mathrm{M})$. The firing was almost completely blocked by the drug (not shown). This indicated that 5-HT acts mainly on nerve fibers expressing TTX-sensitive $\mathrm{Na}^{+}$channels at peripheral terminals, which can be afferents of both Aס- and C-type (Pinto et al., 2008).

\section{Spectral analysis of 5-HT-induced firing}

Intensity of pain depends on the total number of spikes generated in the nociceptive fibers as well as on the frequency of spike discharges (Tong and MacDermott, 2014; Zhang et al., 2004). Therefore, we compared the prevailing discharge frequencies of responders (notably, here each cluster corresponded to a single fiber) in control and after 5-HT application by analyzing the peaks of their interspike interval distributions (Fig. 5A and B). In control, the $\delta$ - $(1 \mathrm{e} 4 \mathrm{~Hz})$ and $\theta$-rhythms $(4 \mathrm{e} 8 \mathrm{~Hz})$ were prevailing in $40 \%$ and $27 \%$ of trigeminal fibers, respectively (Fig. $5 \mathrm{~A}$ and $\mathrm{B}$ ). Autocorrelogram analysis was used to separate and analyze the clusters originating from single fibers (Fig. 5C).

In the presence of $20 \mu \mathrm{M} 5-\mathrm{HT}$, the prevailing frequency of responders still corresponded to the $\delta-(43 \%)$ and $\theta$-rhythms (27\%). However, the number of fibers firing at these frequencies became much higher with respect to control (Fig. 5A). In some fibers, 5-HT additionally induced firing at a frequency around $17 \mathrm{~Hz}$ (Fig. 5A), which could facilitate temporal summation of excitatory inputs on the brainstem or spinal dorsal horn neurons (Zakharov et al., 2015).

\section{Receptor mediating the peripheral 5-HT effect}

One of aims of this study was to identify the type of 5-HT receptor mediating direct excitation of the trigeminal nerve terminals. Since previous studies suggested the role of ionotropic 5-HT3 receptor (see Introduction), we first tested the effect of the specific 5HT3 antagonist MDL-72222 (30 $\mu \mathrm{M})$ on the 5-HT-induced discharge in the meningeal terminals. We found that an increase in the overall firing activity evoked in the meningeal nerve by $20 \mu \mathrm{M} 5$ - HT (to $801 \pm 174 \%, p=0.0002$, n=13, Fig. 6A and C) was considerably

\author{
,
}


reduced in the presence of MDL-72222 (to $280 \pm 70 \%, n=9, p=0.0062$ vs 5 -HT alone, Fig. 6B and $\mathrm{C}$ ).

These results suggested the important role of $5-\mathrm{HT} 3$ receptors in the action of 5-HT. Consistent with this view, the selective $5-\mathrm{HT} 3$ agonist $\mathrm{mCPBG}$ at low concentrations $(0.2$ $\mu M$ ) significantly increased nociceptive firing (to $233 \pm 40 \%, p=0.008, n=8$, Fig. $6 \mathrm{D}$ ) and this effect was abolished by MDL-72222 (70 $\pm 15 \%, p=0.19, n=5$, Fig. 6D).

Interestingly, the compound GR127935 known as the 5-HT1B/D receptor antagonist, in concentration $10 \mu \mathrm{M}$, also reduced the effect of $5-\mathrm{HT}(244 \pm 30 \%, \mathrm{n}=6, \mathrm{p}=0.0066$ vs $5-\mathrm{HT}$ alone, Fig. 6C). A combination of MDL-72222 and GR127935 completely suppressed the 5$H T$-induced increase in discharge of the trigeminal nerve terminals $(133 \pm 43 \%, p=0.44$, $\mathrm{n}=5$, Fig. $6 \mathrm{C}$ ). These data suggested the additional contribution of other $5-\mathrm{HT}$ receptor subtypes sensitive to GR127935.

To test the role of $5-\mathrm{HT} 1 \mathrm{~B} / \mathrm{D}$ receptors we used their selective agonist sumatriptan. However, sumatriptan $(20 \mu \mathrm{M})$ did not change significantly firing in meningeal terminals $(123 \pm 25 \%, p=0.44, n=5$, Fig. $6 \mathrm{D})$ suggesting the minor role of $5-\mathrm{HT} 1 \mathrm{~B} / \mathrm{D}$ receptors in the pro-nociceptive effect of 5-HT. Combination of mCPBG and sumatriptan increased spiking activity to $274 \pm 52 \%(p=0.031, n=6$, Fig. $6 \mathrm{D})$ and this effect was not significantly different from the action of mCPBG alone $(\mathrm{p}=0.43)$. MDL-72222 $(30 \mu \mathrm{M})$ applied after development of the 5 - $\mathrm{HT}$-induced effect slightly reduced firing rate (to $71 \pm 9 \%, \mathrm{p}=0.046, \mathrm{n}=7$ ).

In order to test directly the presence of $5-\mathrm{HT} 3$ in trigeminal neurons we compared membrane currents activated by application of $20 \mu \mathrm{M} 5-\mathrm{HT}$ and the specific agonist mCPBG $(20 \mu \mathrm{M})$ to isolated cultured cells. $5-\mathrm{HT}$ induced currents in $23 \%(45 / 192)$ of neurons whereas mCPBG activated 21\% (13/60) of neurons. Fig. 6E shows typical desensitizing currents induced by paired (interval 5 s) applications of these agonists. Notably, in contrast to $5-\mathrm{HT}$ activated currents which recovered in few seconds, second application of $\mathrm{mCPBG}$ in $5 \mathrm{~s}$ induced no current (Fig. 6E) suggesting prolonged desensitization state for 5 HT3 receptors activated by $\mathrm{mCPBG}$.

Immunohistochemical labelling of the meninges was carried out to localize the 5-HT3 receptors in the dural trigeminal nerves. Omission of secondary antibodies and preincubation of primary antibodies with a corresponding peptide served as negative controls. Nerve fibers immunopositive to $5-\mathrm{HT} 3 \mathrm{~A}$ receptors were found in close proximity to the dura mater blood vessels (Fig. 6F). Some 5- HT3-receptor-positive fibers contained neurofilaments (Fig. 6F), a neurochemical marker of myelinated A-fibers (Bae et al., 2015; Vang et al., 2012), whereas others did not (not shown).

Taken together, these results suggested a major role of $5-\mathrm{HT} 3$ receptors in activation of the trigeminal nerve terminals by $5-\mathrm{HT}$. 


\section{A cluster spike analysis}
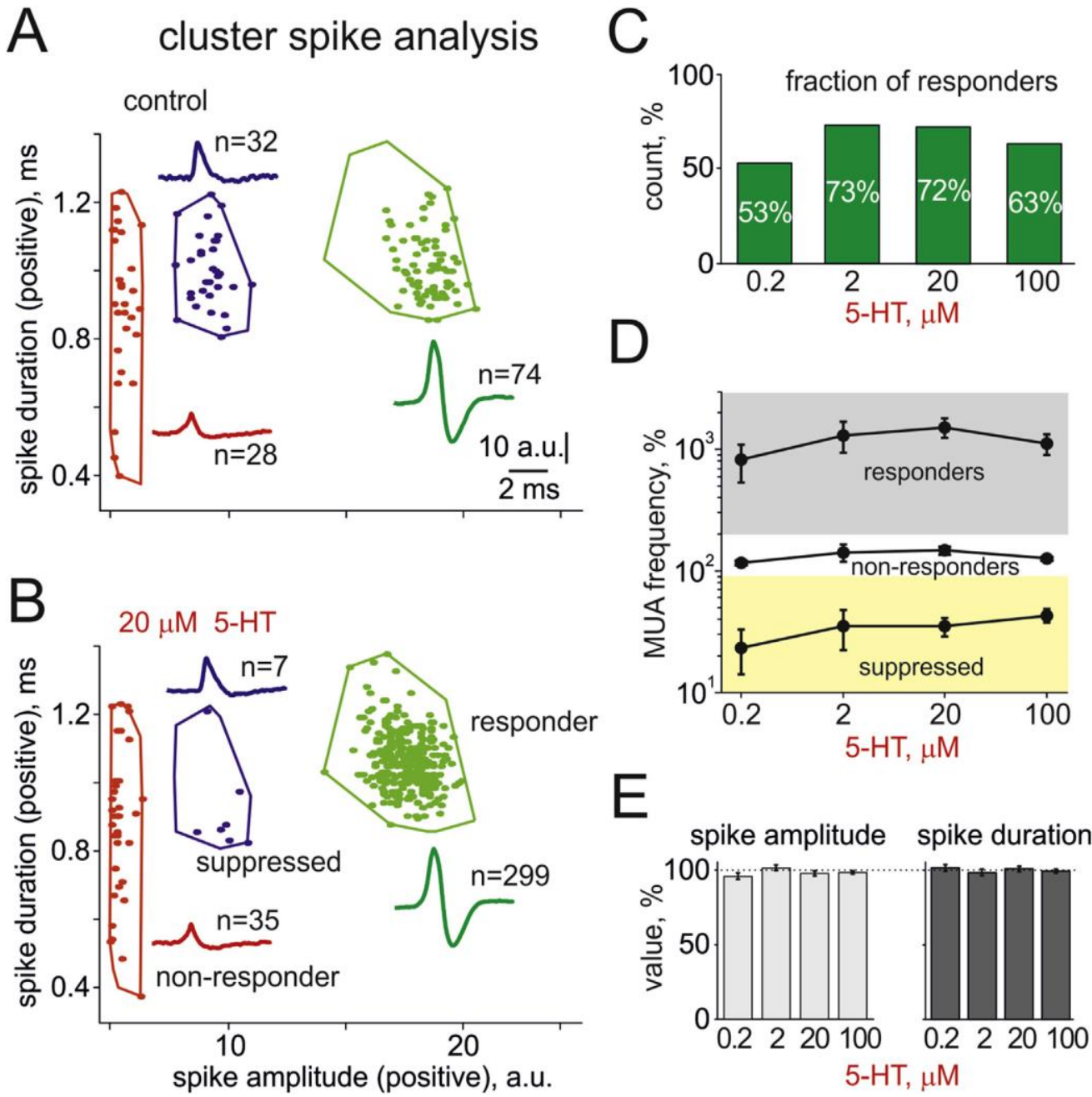

Fig. 2. Cluster spike analysis.

(A) Control spike clusters separated by plotting the duration of the positive wave of the spike versus its amplitude. For each cluster, the number of individual spikes (n) is given together with the averaged spike shape.

(B) The same clusters identified in the presence of $20 \mu \mathrm{M} 5-\mathrm{HT}$.

(C) Fraction of 'responders' as a function of $5-\mathrm{HT}$ concentration. The cluster was considered as a 'responder' when an increase in frequency exceeded $200 \%$.

(D) Dose-response curves for 'responder' (increase in frequency $>200 \%$, upper line), 'non-responder' (middle) and suppressed (decrease in frequency $>10 \%$, lower) clusters. Symbols indicate mean value, vertical bars show SEM.

(E) Averaged spike amplitudes and durations for responders in the presence of different $5-\mathrm{HT}$ concentrations. Data from 4 to 13 preparations were normalized to the corresponding controls. Note that $5-\mathrm{HT}$ did not change the parameters of individual spikes. 

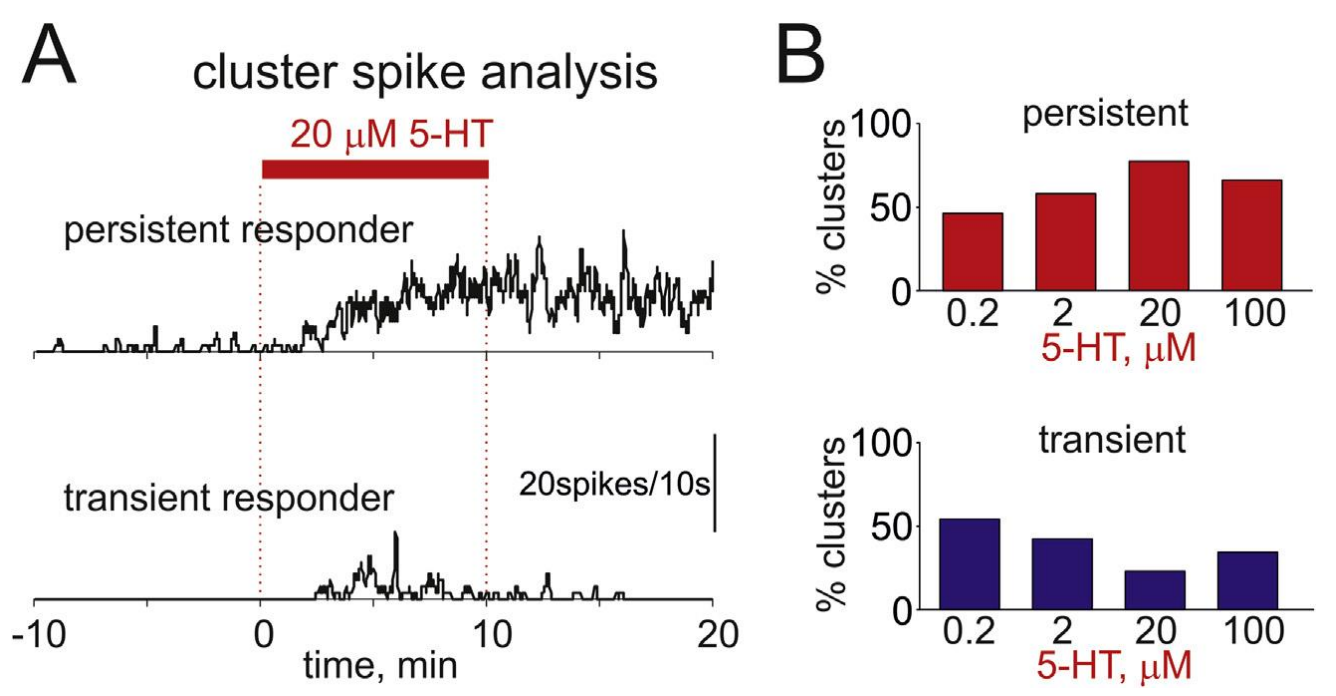

Fig. 3. The time course of 5-HT-induced activity in individual clusters in nervus spinosus.

(A) Examples of $20 \mathrm{mM} 5$ - $\mathrm{HT}$-evoked persistent and transient firing. A $250 \mathrm{~s}$ time point was used as a formal border separating persistent from transient clusters.

(B) Histograms showing the fraction of persistent and transient responders for different 5-HT concentrations.

A cluster spike analysis

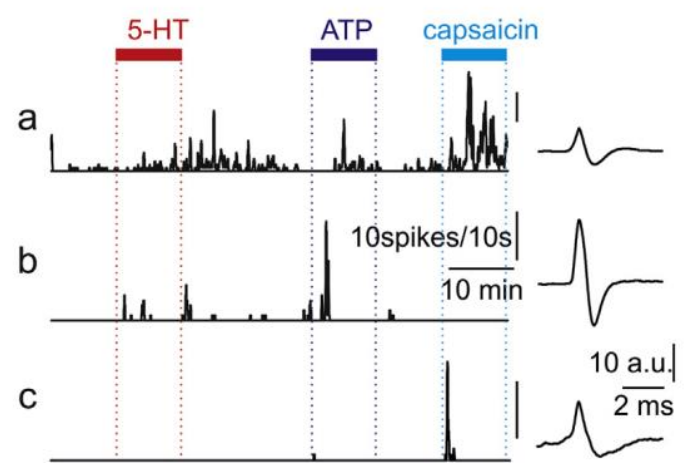

B

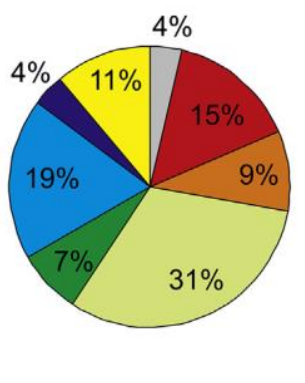

Fig. 4. Co-expression of peripheral 5-HT receptors with receptors for ATP and capsaicin.

(A) Examples of clusters responding to $20 \mu \mathrm{M} 5-\mathrm{HT}$, $100 \mu \mathrm{M}$ ATP and $1 \mu \mathrm{M}$ capsaicin (Aa), to $5-\mathrm{HT}$ and ATP (Ab) and to capsaicin only (AC).

(B) Diagram showing the percentage of clusters with different neurochemical profiles. Results from 5 preparations. 
A cluster spike analysis

control

$5-\mathrm{HT}$
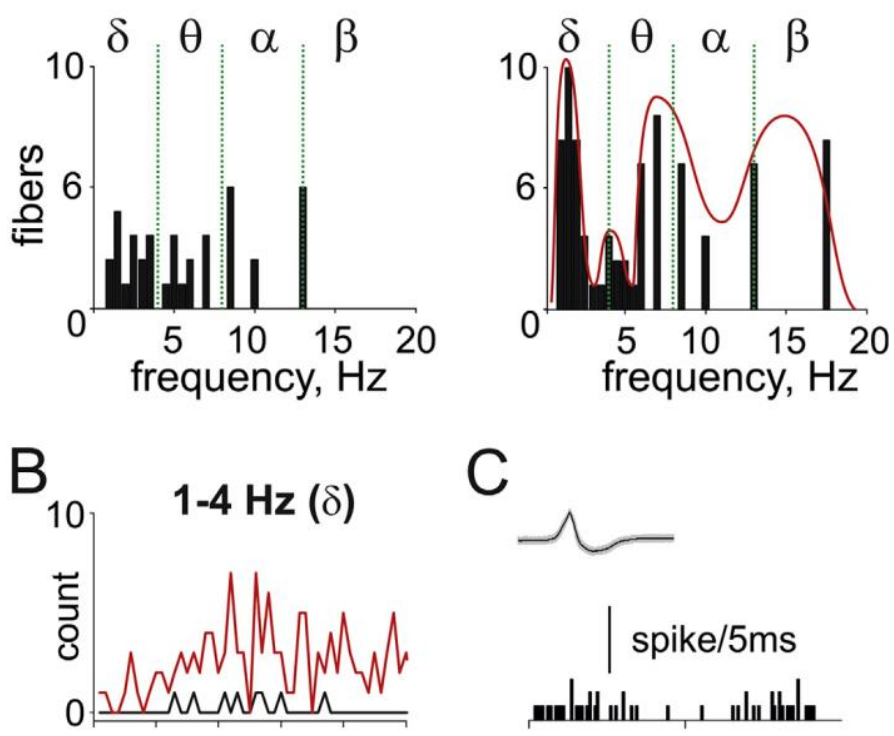

C

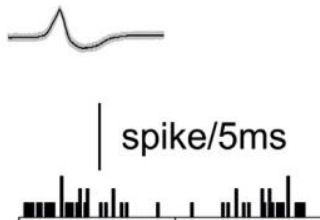

4-8 Hz $(\theta)$
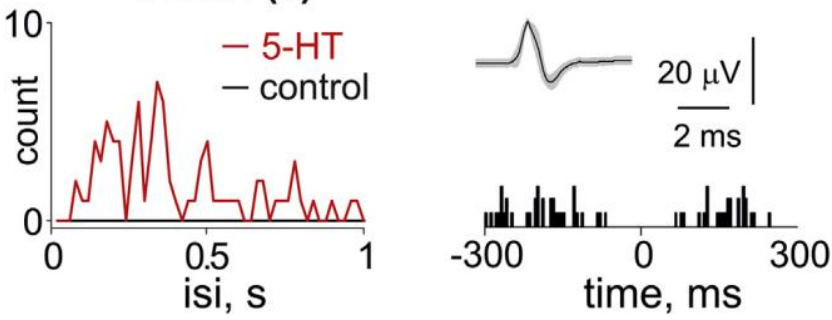

Fig. 5. Co- Spectral analysis of firing in control conditions and in the presence of 5-HT.

(A) Distribution of clusters according to their firing frequency in control and in $20 \mu \mathrm{M} 5$-HT. Note prevailing firing with $\delta$ - and $\theta$-rhythms and essential activity around $17 \mathrm{~Hz}$ in 5 - $\mathrm{HT}$.

(B) Examples of the interspike interval distributions with peaks corresponding to the $\delta$ - and $\theta$-rhythms. Black line, control; red line, $20 \mathrm{mM}$ 5-HT.

(C) Spike shapes and respective auto-correlograms for the clusters shown in B. (For interpretation of the references to colour in this figure legend, the reader is referred to the web version of this article.) 


\section{Meningeal ast cells as a potential 5-HT source}

Since 5-HT is contained in granules of dural mast cells (Levy, 2009), we tested whether they may serve as a source of endogenous $5-\mathrm{HT}$ release in the cranial meninges to activate local afferents. As expected, application of the compound $48 / 80$ at $10 \mu \mathrm{g} / \mathrm{ml}$ concentration to meninges evoked degranulation of the mast cells in our hemiskull preparation (Fig. 7A). This application also induced a persistent nociceptive firing in the trigeminal nerve endings $(250 \pm 43 \%$ of control, $p=0.0001, n=27$, Fig. 7B). The $5-H T 3$ receptor antagonist (MDL-72222, $30 \mu \mathrm{M})$ prevented effect of the compound 48/80 on firing $(p=0.72, n=6$, Fig. $7 C)$, suggesting that endogenous $5-H T$ contributed to the excitation of nerve terminals caused by the mast cell degranulation. Histamine $(100 \mu M)$, which could be also released from mast cells, produced only insignificant increase in the afferent firing $(126 \pm 17 \%, p=0.16, n=6$, Suppl Fig. $1 \mathrm{~A}$ and $\mathrm{C})$, whereas lowering $\mathrm{pH}$ to 5.4 which is often used for preparation of the inflammatory soup, largely facilitated spiking activity (1053 \pm
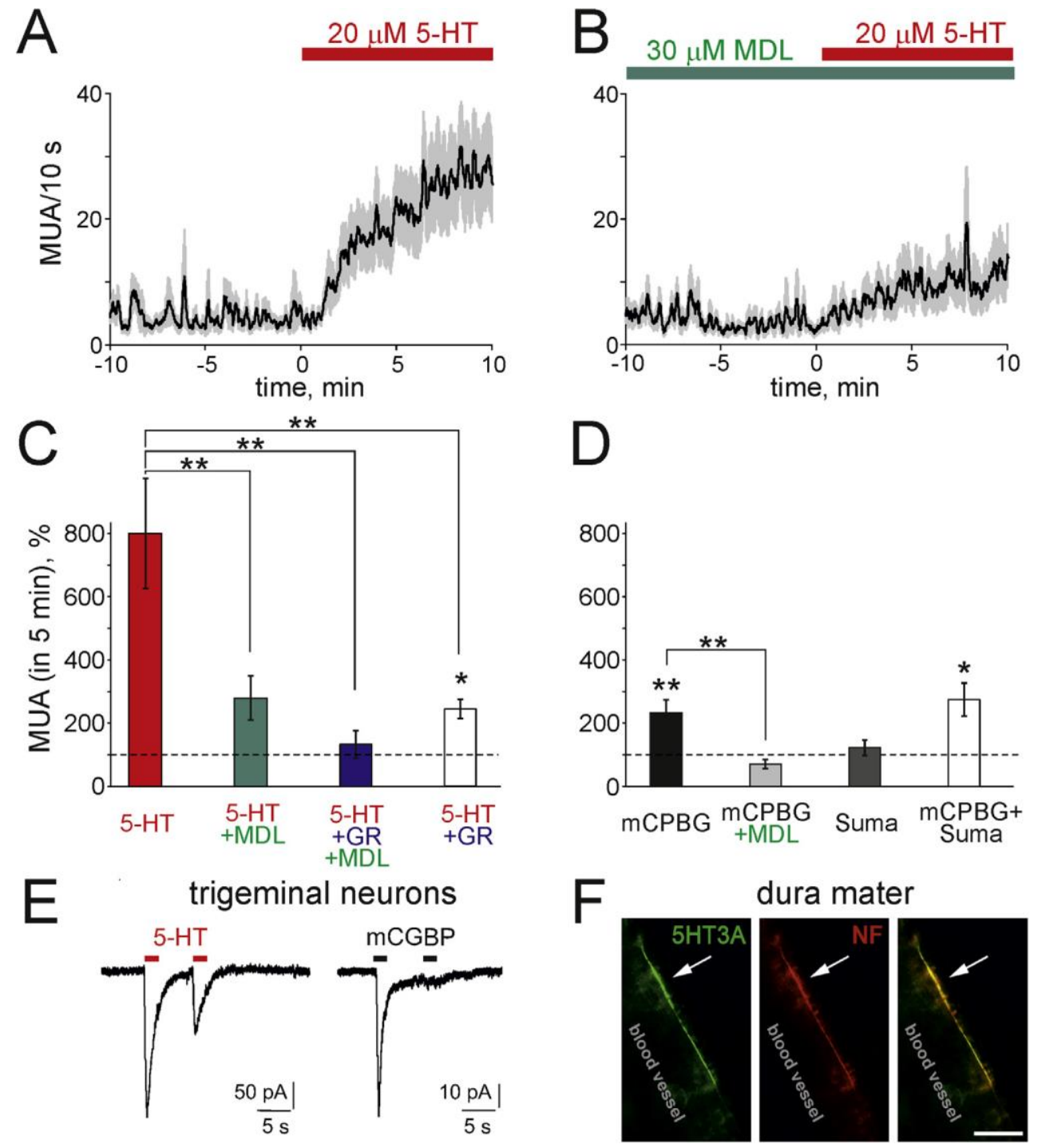
474\%, $p=0.0039, n=9$, Suppl Fig. 1B and C) like the powerful pro-nociceptive capsaicin (Suppl Fig. 1C).

Fig. 6. Receptors mediating the 5 -HT-induced multiple unit activity in nervus spinosus.

(A) Multiple units (MU) density in the nervus spinosus before and during the application of $20 \mu \mathrm{M} 5$ - $\mathrm{HT}$ (13 experiments).

(B) MU density in the nervus spinosus during application of the specific 5 eHT3 receptor antagonist MDL-72222 $(30 \mu \mathrm{M})$ alone and together with $20 \mu \mathrm{M} 5$ - $\mathrm{HT}$ (9 experiments).

(C) Histograms showing the effect on firing of $20 \mu \mathrm{M} 5-\mathrm{HT}$ alone, $30 \mu \mathrm{M}$ MDL-72222 with $20 \mu \mathrm{M}$ serotonin, the specific 5eHT1B/D receptor blocker GR127935 (10 $\mu \mathrm{M})$ with $30 \mu \mathrm{M}$ MDL-72222 and $20 \mu \mathrm{M} 5$-HT, blocker GR127935 (10 $\mu \mathrm{M})$ with $20 \mu \mathrm{M} 5$-HT. Spiking activity was counted for 5 min and plotted as percentage of period prior drugs application. Data from five to 13 experiments. * $p<0.05 ; * * p<0.01$.

(D) Histograms showing the action of the specific $5-\mathrm{HT}_{3}$ receptor agonist mCPBG $(0.2 \mu M)$, mCPBG in the presence of $30 \mu \mathrm{M} M D L-72222$, and action of the specific $5-\mathrm{HT}_{1} \mathrm{~B} / \mathrm{D}$ receptor agonist sumatriptan $(20 \mu \mathrm{M})$ and the combined action of $0.2 \mu \mathrm{M}$ mCPBG plus $20 \mu \mathrm{M}$ sumatriptan. Spiking activity was recorded for 5 min and plotted as percentage of control. Data from five to 8 experiments.

(E) Membrane currents in trigeminal neurons activated by paired (interval $5 \mathrm{~s}$ ) application for $2 \mathrm{~s}$ of $20 \mu \mathrm{M} 5$ - $\mathrm{HT}$ (left) and $20 \mu \mathrm{M} \mathrm{mCPBG}$ (right). Notice very poor recovery of currents after first application of $m$ CPBG.

(F) Immunohistochemical staining of $5 \mathrm{eHT}_{3} \mathrm{~A}$ receptor expressed in a sensory nerve fiber, which localized near the blood vessel in cranial dura mater. The nerve fiber was costained with antibodies against the light chain of neurofilaments (NF) that revealed the neurochemical profile of the myelinated A-fiber (merged image, right).

\section{HT-evoked $\mathrm{Ca}^{2+}$ transients in the trigeminal cells}

As somata of trigeminal neurons could also contribute to the nociceptive signaling (Amir and Devor, 1996; Thalakoti et al., 2007) we tested the action 5-HT on trigeminal ganglion cells. The $\mathrm{Ca}^{2+}$ imaging technique was also used to study functional expression of 5-HT receptors in the trigeminal ganglion neurons and satellite glial cells (SGCs). To better characterize responding cells, effect of $20 \mu \mathrm{M} 5$ - HT was compared with that of $1 \mu \mathrm{M}$ capsaicin. We used the cell permeable $\mathrm{Ca}^{2+}$ indicator fluo-3AM to measure changes in the level of intracellular $\mathrm{Ca}^{2+}$. Cell stimulation with 5-HT (for $20 \mathrm{~s}$ ) and capsaicin (for $2 \mathrm{~s}$ ) was followed by the application of a solution containing $50 \mathrm{mM} \mathrm{KCl}$, to distinguish neurons from the SGCs (Simonetti et al., 2006). The 5-HT application evoked fast intracellular $\mathrm{Ca}^{2+}$ transients in 33 of 154 neurons (21\%, Fig. $8 \mathrm{~A}$ and $\mathrm{B})$. The majority of $5-\mathrm{HT}$ sensitive neurons also responded to capsaicin (70\%, Fig. $8 \mathrm{~A}$ and $\mathrm{B}$ ) indicating the functional coexpression of 5-HT and TRPV1 receptors. It should be noted that higher number of neurons in our preparation responded to capsaicin only (Fig. 8B). In addition, 5-HT excited a fraction of SGCs (29 of 138 cells, $21 \%$, Fig. 8 A and C). The 5-HT3 receptor agonist mCPBG $(2 \mu M)$ activated 9 of 34 trigeminal neurons (26\%, not shown). However, mCPBG had no effect on SGCs indicating the predominant neuronal expression of 5-HT3 receptors. In agreement with this, 5-HT-evoked $\mathrm{Ca}^{2}+$ transients in neurons disappeared in $\mathrm{Ca}^{2+}$-free bath solution indicating that they were mediated by the extracellular $\mathrm{Ca}^{2+}$ influx (Suppl Fig. $2 \mathrm{~A})$. In contrast, responses of trigeminal satellite glial cells persisted in $\mathrm{Ca}^{2+}$-free bath solution suggesting that they were mostly mediated by $\mathrm{Ca}^{2+}$ release from the intracellular stores (Suppl Fig. 2B).

Thus, a fraction of trigeminal ganglion cells expressed functional 5-HT3 receptors, which were responsible for the 5-HT-induced firing in the peripheral nerve terminals. Furthermore, the 5-HT receptors were mainly found in a subpopulation of peptidergic neurons expressing TRPV1 receptors (Julius and Basbaum, 2001) predicting that 5-HT may evoke CGRP release. 

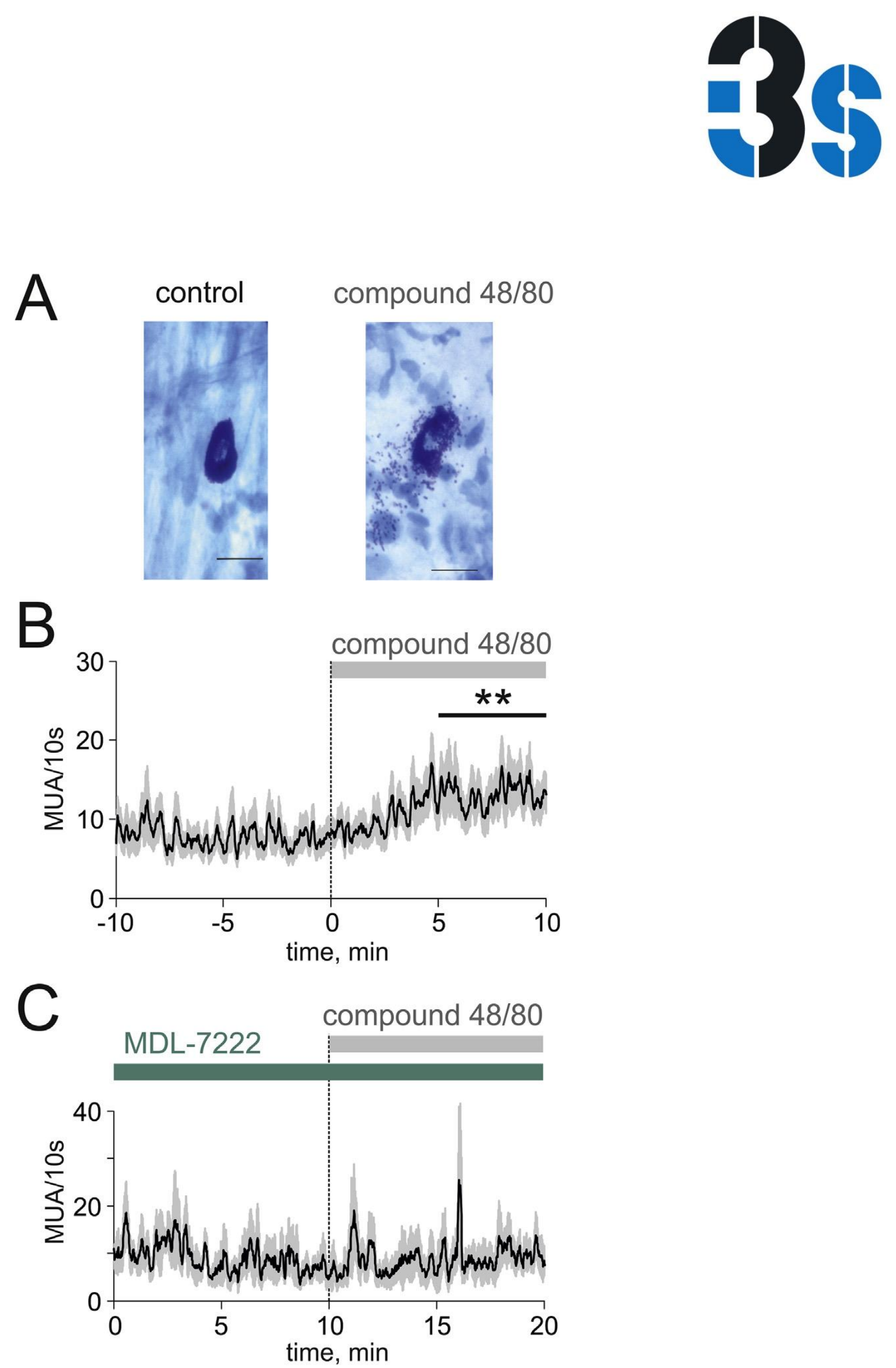

Fig. 7. Mast cells and endogenous 5-HT-induced nociceptive firing. 
(A) Examples of an intact meningeal mast cell in control and a degranulated mast cell after application of the compound $48 / 80$ (10 $\mu \mathrm{g} / \mathrm{ml}$, staining with Tolvidine Blue). Calibration bar $10 \mu \mathrm{m}$.

(B) MUA in the nervus spinosus before and during the application of the mast cell degranulating agent (compound 48/80, $10 \mu \mathrm{g} / \mathrm{ml}, 27$ experiments). $* * *, \mathrm{p}<0.001$.

(C) MUA in the nervus spinosus during the application of MDL-72222 (30 $\mu \mathrm{M})$ or MDL-7222 with compound $48 / 80(10 \mu \mathrm{g} / \mathrm{ml})$. Note that the $5-\mathrm{HT}_{3}$ receptor antagonist prevented firing induced by degranulation (6 experiments). (For interpretation of the references to colour in this figure legend, the reader is referred to the web version of this article.)

A

trigeminal ganglion
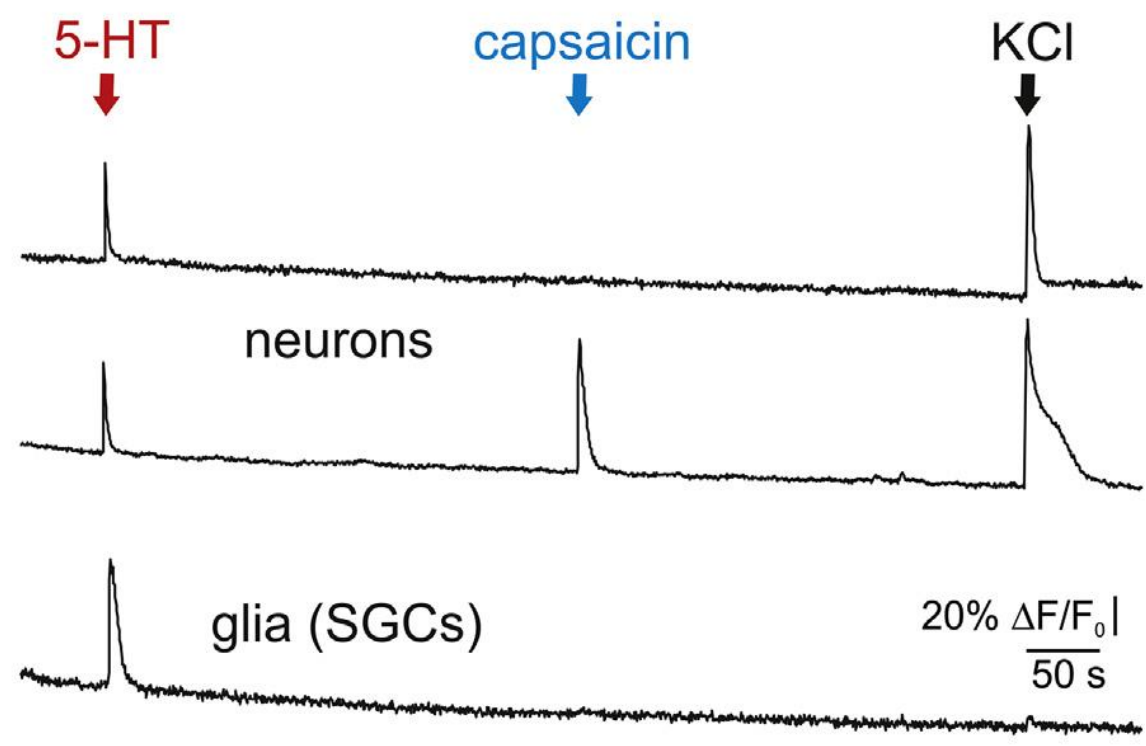

B
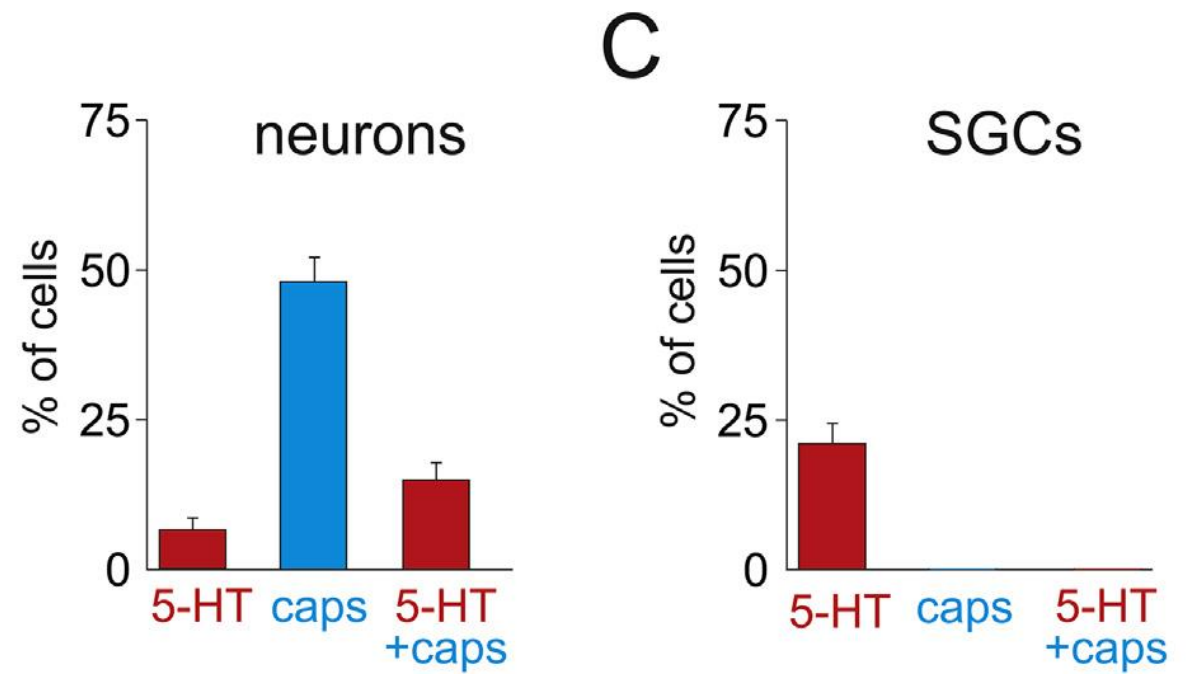

Fig. 8. Ca2+ transients activated by 5-HT. 
(A) Changes in the intracellular $\mathrm{Ca}^{2+}$ level after applications of $20 \mu \mathrm{M} 5-\mathrm{HT}, 1 \mu \mathrm{M}$ capsaicin and $50 \mathrm{mM}-\mathrm{KCl}-$ containing solution in the trigeminal ganglion neurons and satellite glial cells (SGC). Some neurons responded to 5-HT only (upper trace) or to both agonists (middle trace). SGCs were sensitive to 5 - $\mathrm{HT}$, but not to capsaicin (lower trace). The $\mathrm{KCl}$-containing solution was applied to distinguish neurons from SGCs.

(B) The fraction of neurons responding to $5-\mathrm{HT}$ only, to capsaicin only and to both agonists (154 neurons).

(C) The percentage of SGC responding to $5-\mathrm{HT}$. SGCS did not respond to capsaicin or a $\mathrm{KCl}$-containing solution (138 S GCs).

\section{Action of 5-HT on CGRP release}

We also studied whether 5-HT can evoke release of the key migraine mediator CGRP, which is stored in large dense core vesicles of peptidergic terminals in the meninges (Durham and Russo, 1999). 5-HT (100 $\mu \mathrm{M})$ was applied to isolated hemiskulls and the level of CGRP was determined using a standard enzyme immuno-assay kit. 5-HT significantly increased the release of CGRP from the trigeminal nerve terminals $(34 \pm 2.9 \mathrm{pg} / \mathrm{ml}$ versus $20 \pm 1.7 \mathrm{pg} / \mathrm{ml}$ in control, $\mathrm{n}=5, \mathrm{p}=0.002$, Fig. $9 \mathrm{~A}$ ). In the presence of $30 \mu \mathrm{M} \mathrm{MDL}-72222$, the 5 - $\mathrm{HT}$-induced release of CGRP was completely prevented $(14.34 \pm 2.4 \mathrm{pg} / \mathrm{ml}$ in $\mathrm{MDL}$ 72222 versus $14.35 \pm 1.2 \mathrm{pg} / \mathrm{ml}$ in MDL-72222 plus $5-\mathrm{HT}, \mathrm{n}=5, \mathrm{p}=0.37$, Fig. 9B). Thus, $5-\mathrm{HT}$ strongly increased the level of CGRP released from the meninges via the 5-HT3 receptor subtype.

In contrast, in the brainstem, $5-\mathrm{HT}(20 \mu \mathrm{M})$ reduced the release of CGRP from $4.32 \pm 0.70$ $\mathrm{pg} / \mathrm{mL}$ to $2.43 \pm 0.69 \mathrm{pg} / \mathrm{mL}(\mathrm{p}=0.017, \mathrm{n}=5)$.

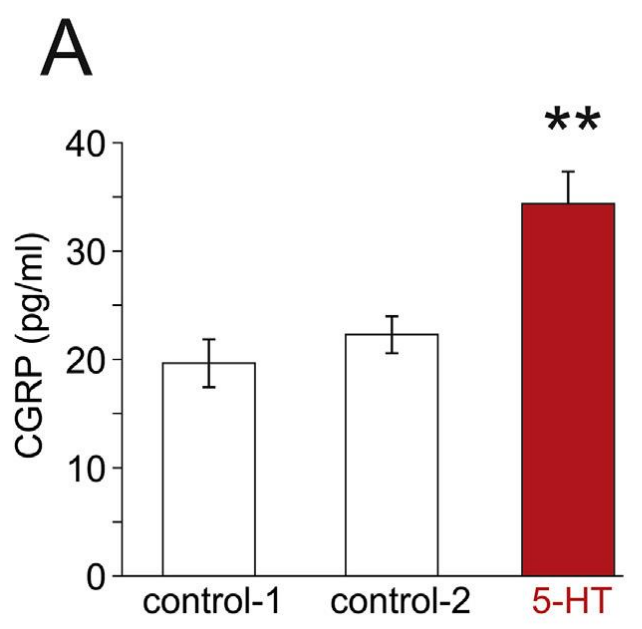

B

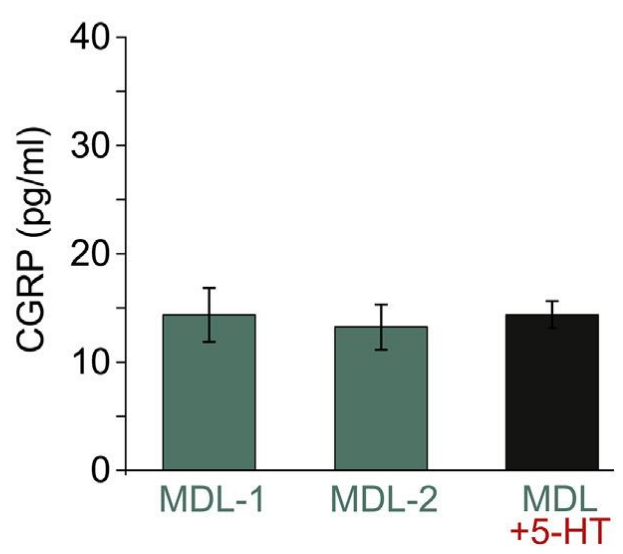

Fig. 9. 5-HT induced CGRP release in meninges.

(A) CGRP concentrations in the meninges in control and after application of $100 \mu \mathrm{M} 5-\mathrm{HT}$. Note the stable control level and significant increase in the CGRP level after the 5 -HT application ( 5 experiments, $* * p<0.01$ ).

(B) CGRP concentrations in the presence of the specific $5-\mathrm{HT}_{3}$ antagonist MDL-72222 $(30 \mu \mathrm{M})$, and MDL-72222 with $100 \mu \mathrm{M} 5-\mathrm{HT}$. The $5-\mathrm{HT}_{3}$ receptor antagonist completely prevented the stimulatory effect of $5-\mathrm{HT}$ (5 experiments). 


\section{HT inhibits the central terminals of trigeminal afferents}

As the central (presynaptic) terminals of the trigeminal nerve relay peripheral nociceptive input to the second order neurons in the trigeminocervical complex, we also tested the 5HT action at this site. The experiments were designed to reveal presynaptic effects induced by 5 -HT. For this, whole-cell recordings from upper cervical lamina I neurons were carried out to analyze the $5-\mathrm{HT}$-induced changes in the magnitude of the monosynaptic EPSCs evoked by stimulating trigeminal $A \delta$ - and C-afferents (Fig. 10, bottom inset). We found that $20 \mu \mathrm{M} \mathrm{5-HT}$ reversibly reduced evoked EPSCs to $39.3 \pm 25.8 \%$ ( $n=8, p$ $<0.05$; Fig. 10A, C). It should be noted that $5-\mathrm{HT}$ had effects on the monosynaptic EPSCs

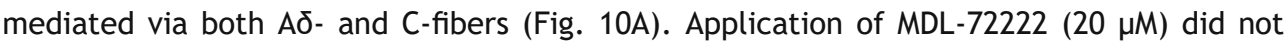
affect the EPSC amplitudes by itself $(113.4 \pm 12.2 \%, n=5, p=0.07$, Fig. $10 B$ and $C)$ but prevented the effect of the following $5-\mathrm{HT}$ application $(105.0 \pm 14.3 \%$ of control, $n=4$, $\mathrm{p}=0.53$; Fig. 10B). These data suggested that $5-\mathrm{HT}$ provides an inhibitory control of the activity of the central terminals of $A \delta$ - and $\mathrm{C}$-fiber trigeminal afferents via presynaptic 5 HT3 receptors.

\section{DISCUSSION}

The main finding of the present study is that $5-\mathrm{HT}$ acting via the $5-\mathrm{HT} 3$ receptor induces a dual effect: powerful long-lasting pro-nociceptive firing along with CGRP release in the peripheral meningeal terminals of the trigeminal nerve, and anti-nociceptive presynaptic inhibition of its central terminals. Our cluster approach revealed a high heterogeneity of the 5-HT effects induced at the level of single trigeminal fibers innervating cranial meninges. Taken together, this study provides a rationale for the region-specific control of nociceptive firing as a basis for specific therapy of migraine pain.

\section{HT receptors in the trigeminal nociceptive system}

5-HT is an endogenous neurotransmitter and neuromodulator operating via several metabotropic receptors and one ionotropic receptor of the 5-HT3 type. There are five subtypes of the 5-HT3 receptor (5-HT3A-E); the 5-HT3A subtype being most widely expressed (Niesler, 2011).

The important role of the $5-\mathrm{HT} 3$ receptor contributing to activation of peripheral branches of meningeal afferents in the current study was confirmed by the inhibitory effect of the selective 5-HT3 blocker MDL-72222 and pro-nociceptive activity of the 5-HT3 agonist mCPBG. Further support was obtained by specific labelling of the trigeminal nerve fibers with the $5-\mathrm{HT} 3 \mathrm{~A}$ receptor antibody and direct activation of $5-\mathrm{HT} 3$ receptor mediated currents in a fraction of trigeminal neurons. It has been shown previously that $5-\mathrm{HT} 3$ receptors are expressed in both myelinated $A \delta$ - and some unmyelinated $\mathrm{C}$-fibers (Martin et al., 1998), and their activation by intraplantar injection of 5-HT evokes acute pain (Sufka et al., 1992). Accordingly, functional elimination of the 5-HT3 receptor reduces tissue injury-induced nociception in mice (Zeitz et al., 2002). 5-HT3 receptors are also involved in vasodilation induced by $5-\mathrm{HT}$ in duramater (Lambert et al., 2004). Here we show that 5HT3 receptors in meningeal fibers mediate also release of the neuropeptide CGRP, a 
principal trigger of migraine, which may cause neurogenic inflammation and migraine headache.

It should be noted however, that although multiple evidence indicates an important role of 5-HT3 receptor in trigeminal nociception, some contribution of other 5-HT receptors cannot be excluded. Indirectly this view is supported by complete prevention of the $5-\mathrm{HT}$ induced firing with combination of MDL-72222 and GR127935. An involvement of 5-HT1B/D receptor is unlikely since sumatiptan alone or with $\mathrm{MCPBG}$ failed to activate firing. Thus, the role of receptors other than 5-HT1B/D, for instance, 5-HT2 receptor (Segelcke and Messlinger, 2016) should be studied in future experiments.

\section{Novel properties of cranial nociceptors revealed by the clustering approach}

Cluster analysis of the trigeminal nerve firing (Zakharov et al., 2015) was used to characterize the responses of individual afferents to 5-HT application. The high percentage of responders $(\sim 70 \%)$ was close to that reported for the trigeminal nerve activation by capsaicin (65\%, Zakharov et al., 2015). The cluster analysis identified highly sensitive trigeminal fibers activated by nanomolar $5-\mathrm{HT}$ concentrations. According to the time-course of the 5-HT-induced discharges, the population of responders was very heterogeneous including persistently activated fibers likely underlying the long-lasting 5$\mathrm{HT}$-induced pain sensitization. Indeed, 5-HT, as a key component of the inflammatory soup (Strassman et al., 1996; Burstein et al., 2005; Oshinsky and Gomonchareonsiri, 2007; Lukács et al., 2015), can induce sensitization of the trigeminal nociceptive system underlying migraine pain. Consistent with the major role of 5-HT, histamine was much less effective.

We have also found that, in addition to an augmentation of the prevailing $\delta$ - and $\theta$-rhythm firing, 5-HT evoked, in individual fibers, a high-frequency discharge at $17 \mathrm{~Hz}$. Such discharge frequencies may be sufficient to induce temporal summation of nociceptive inputs in the spinal dorsal horn neurons (Zakharov et al., 2015) and ensure their relay to higher pain centers. 


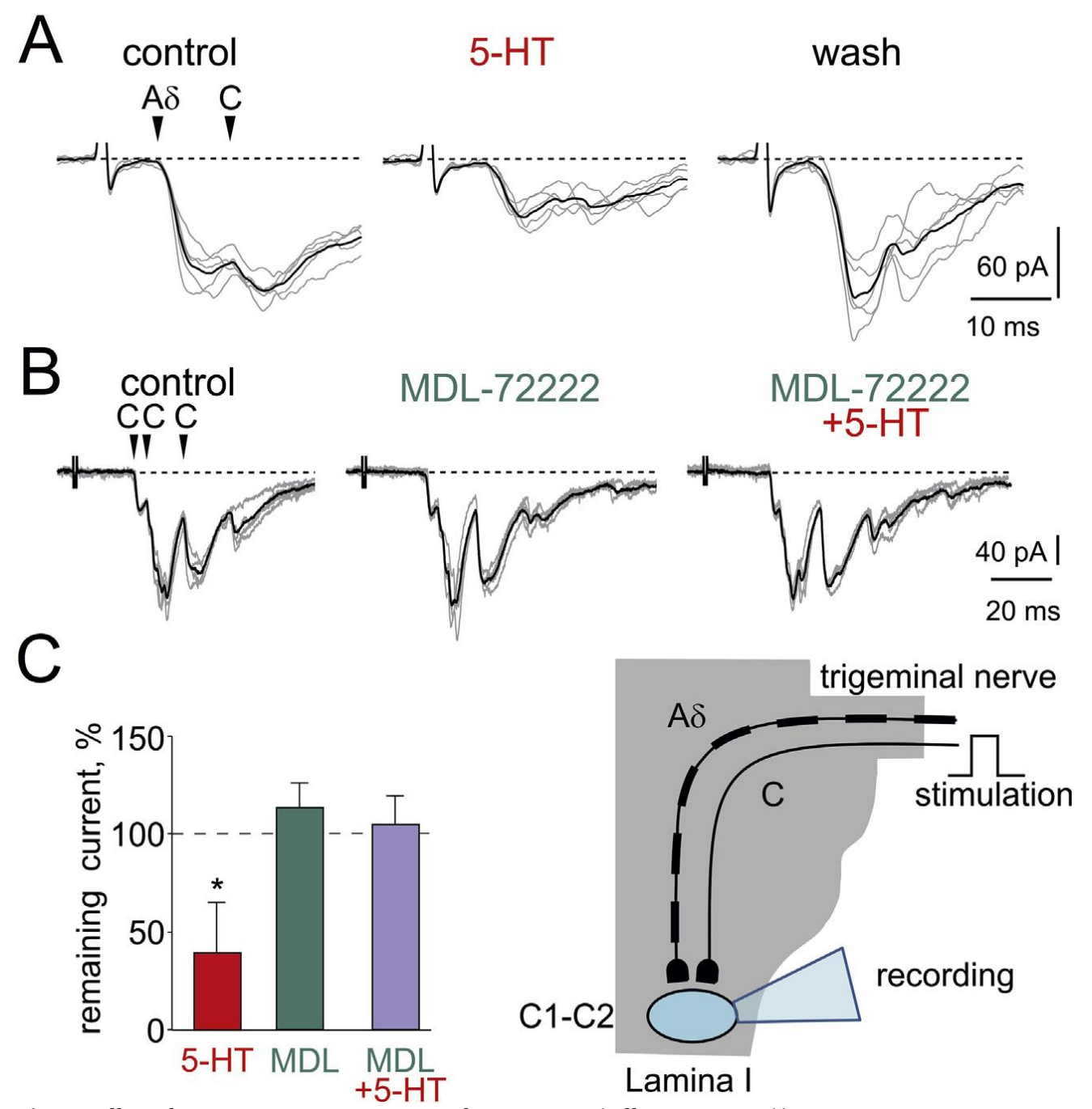

Fig. 10. Effect of $5-\mathrm{HT}$ on synaptic transmission from trigeminal afferents to spinal lamina I neurons.

(A) Monosynaptic EPSCs mediated via A $\delta$ - and C-fibers evoked in a spinal lamina I neuron by stimulating the trigeminal nerve in control, $20 \mu \mathrm{M} 5-\mathrm{HT}$ and after washout. Each family represents 5 consecutive responses (grey) and their average (black). Here and in $\mathrm{B}$; the monosynaptic $\mathrm{A} \delta$ - and C-fiber-mediated components are indicated by arrowheads, the holding potential was $-70 \mathrm{mV}$, and the stimulation pulse duration was $1 \mathrm{~ms}$.

(B) The specific $5 \mathrm{eHT}_{3}$ receptor antagonist MDL-72222 $(20 \mu \mathrm{M})$ prevented reduction of the C-fiber-mediated EPSCs by $5-\mathrm{HT}(20 \mu \mathrm{M})$.

(C) The EPSC amplitudes in $5-\mathrm{HT}$, MDL-7222, and MDL with $5-\mathrm{HT}$ normalized to control. Significant effect is indicated by *. The inset shows a diagram of the experiment.

\section{HT-induced Ca2+ transients and CGRP release}

5-HT excited somata of trigeminal ganglion neurons, which are also considered as potential contributor to migraine pain (Messlinger, 2009). We have found that neuronal cell bodies and a fraction of the trigeminal satellite cells responded to 5 -HT by elevation of intracellular $\mathrm{Ca}^{2+}$. This neuronal response could be caused, at least in part, by the direct $\mathrm{Ca}^{2+}$ influx via the 5-HT3 receptor ion channel, which has relatively high $\mathrm{Ca}^{2+}$ 
permeability (Ronde' and Nichols, 1998). Such $\mathrm{Ca}^{2+}$ elevation can initiate neuronal sensitization via the $\mathrm{Ca}^{2+}$-dependent enzyme CaMKII contributing to migraine pain (Simonetti et al., 2008). Interestingly, the majority of the 5-HT-sensitive trigeminal neurons, similarly to peripheral nerve terminals co-expressed TRPV1 and 5-HT receptors, providing a rationale to our previously found enhancement of capsaicin-activated currents by 5-HT (Simonetti et al., 2006).

The increase in the CGRP release in the dura mater mediated via the 5-HT3 receptor described here can, along with other pro-inflammatory agents, such as substance $\mathrm{P}$, prostaglandins (Ebersberger et al., 1999) sensitize trigeminal system. CGRP induces neurogenic inflammation of the dura mater (Olesen et al., 2009), probably via vasodilation and directly causing activation of neurons (Markowitz et al., 1987), it can trigger ATP release (Yegutkin et al., 2016) and up-regulate the expression of pain-transducing P2X3 receptors (Giniatullin et al., 2008). Thus, CGRP released in meninges could further augment afferent sensitization. Such sensitization can include activation of PKC, PKA and CaMKII, which, in turn, can enhance pain transduction by P2X3 receptors via protein trafficking and CREB-dependent transcription (Simonetti et al., 2008; Giniatullin and Nistri, 2013).

Thus, 5-HT demonstrated several pro-nociceptive effects in the peripheral part of the trigeminal system. It enhanced nociceptive firing in meningeal terminals, elevated intracellular $\mathrm{Ca}^{2+}$ in trigeminal ganglion neurons and satellite cells, and triggered the release of the algogen CGRP.

\section{HT3 receptors at central terminals of Aס- and C-afferents}

5-HT3 receptors are also expressed in the central terminals of afferents (Martin et al., 1998) where they modulate nociceptive inputs to the spinal cord (Khasabov et al., 1999). Lamina I is the major output unit of the spinal nociceptive network. Neurons in the upper cervical cord, a part of the trigeminocervical complex, relay afferent inputs from the cranial meninges and cervical somatic structures, and serve as the neural substrate of primary headache syndrome (Bartsch and Goadsby, 2003). We found that the 5-HT3 receptor essentially contributes to the $5-\mathrm{HT}$ induced presynaptic inhibition of $\mathrm{A} \delta$ - and Cafferents supplying lamina I neurons and therefore can effectively control the nociceptive drive to the spinal cord. This 5-HT3-receptor-mediated inhibition may function via depolarization of primary afferents and inactivation of the voltagegated $\mathrm{Na}^{+}$channels leading to reduced involvement of $\mathrm{Ca}^{2+}$ channels responsible for transmitter release in the central terminals (Rudomin and Schmidt, 1999). The presynaptic inhibition may be caused by the tonic activity of serotonergic neurons located in the rostral posterior medulla (RPM, $\mathrm{Kim}$ et al., 2014). Such central control may involve direct synapses of serotonergic descending axons onto the central terminals of primary afferents (Zhang et al., 2015). The inhibitory central effect of $5-\mathrm{HT}$ on synaptic transmission was consistent with the depressant action of 5-HT on CGRP release in the brainstem which could also involve 5HT1B/D receptors (Goadsby and Edvinsson, 1993; Goadsby and Hoskin, 1998; Donaldson et al., 2002 Amrutkar et al., 2012). However, given the complicated local neuronal network in the spinal dorsal horn and brainstem, the central effects of $5-\mathrm{HT}$ are likely involve several subtypes of $5-\mathrm{HT}$ receptors. Moreover, in certain pain conditions there are could 
be alterations in descending serotonergic modulation of the nociceptive pathways (Kim et al., 2014). Taken together, the current evidence suggests that central serotonergic control is tunable and could be differently presented in normal versus pain conditions.

\section{Pathophysiological implications in migraine}

Our results suggest that 5-HT released from dural mast cells (Levy, 2009; Tore and Tuncel, 2011) and/or aggregated platelets (Taffi et al., 2005) induces nociceptive firing in nerve terminals. The effect can become long-lasting due to contributing vasodilation (Lambert et al., 2004), extravasation (Williamson et al., 1997) and neuro-inflammation triggered by multiple pro-inflammatory compounds, including ATP (Yegutkin et al., 2016) and CGRP (Markowitz et al., 1987; Fabbretti et al., 2006). However, activation of the peripheral meningeal nerve endings by 5 -HT could be counterbalanced, by its inhibitory action on the central terminals synapsing on lamina I neurons in the brainstem and upper cervical spinal cord. The weakening of this presynaptic inhibition in migraine can 'open gates' for peripheral pain signals. The balance between excitatory peripheral and central inhibitory effects could determine the final contribution of $5-\mathrm{HT}$ to the migraine pain state.

\section{CONCLUSION}

In conclusion, we report a robust nociceptive activity and CGRP release induced by 5 -HT in peripheral nerve terminals mainly via 5-HT3 receptors. Cluster analysis revealed highly heterogeneous profiles of nociceptive activity including long-lasting firing. $\mathrm{Ca}^{2+}$ imaging indicated essential co-expression of 5-HT and TRPV1 receptors in trigeminal neurons. Interestingly, peripheral nociceptive activation was combined with the inhibitory action of $5-\mathrm{HT}$ at central nerve terminals of meningeal nociceptors through the same $5-\mathrm{HT} 3$ receptor. Thus, our data suggest that $5-\mathrm{HT}$ plays a dual role in migraine: multicomponent pro-nociceptive peripheral action and inhibitory effect in the central terminals of meningeal nociceptors.

\section{CONFLICT OF INTEREST}

The authors declare that the research was conducted in the absence of any commercial or financial relationships that could be construed as a potential conflict of interest.

\section{ACKNOWLEDGEMENT}

The authors declare that the research was conducted in the absence of any commercial or financial relationships that could be construed as a potential conflict of interest. The study was supported by the Finnish Academy (grant 277442). AZ was supported by the subsidy allocated to Kazan Federal University for the state assignment in the sphere of scientific activities and the Government of the Russian Federation (grant No.11.G34.31.0075). The work of IS was supported by RFBR grant 14-04-00885. BVS was supported by the grant from 
the Fundação para a Ciência e a Tecnologia (PTDC/NEU-NMC/1259/2014) and from the programme NORTE 2020.

\section{APPENDIX A. SUPPLEMENTARY DATA}

Supplementary data related to this article can be found at http:// dx.doi.org/10.1016/j.neuropharm.2016.12.024.

\section{REFERENCES}

Amir, R., Devor, M., 1996. Chemically mediated cross-excitation in rat dorsal root ganglia. J. Neurosci. 16, $4733 e 4741$.

Amrutkar, D.V., Ploug, K.B., Hay-Schmidt, A., Porreca, F., Olesen, J., Jansen-Olesen, I., 2012. mRNA expression of 5 -hydroxytryptamine $1 B, 1 D$, and $1 F$ receptors and their role in controlling the release of calcitonin geneerelated peptide in the rat trigeminovascular system. Pain 153, 830e838. http://dx.doi.org/10.1016/j.pain.2012.01.005.

Bae, J.Y., Kim, J.H., Cho, Y.S., Mah, W., Bae, Y.C., 2015. Quantitative analysis of af- ferents expressing substance $\mathrm{P}$, calcitonin gene-related peptide, isolectin $\mathrm{B}_{4}$, neurofilament 200 , and Peripherin in the sensory root of the rat trigeminal ganglion. J. Comp. Neurol. 523, 126e138. http://dx.doi.org/10.1002/cne.23672.

Bartsch, T., Goadsby, P.J., 2003. The trigeminocervical complex and migraine: cur- rent concepts and synthesis. Curr. Pain Headache Rep. 7, 371e376. http:// dx.doi.org/10.1007/s11916-003-0036-y.

Borgdorff, P., Tangelder, G.J., 2012. Migraine: possible role of shear-induced platelet aggregation with serotonin release. Headache 52, 1298e1318. http://dx.doi.org/ 10.1111/j.1526-4610.2012.02162.x.

Burstein, R., Jakubowski, M., Levy, D., 2005. Anti-migraine action of triptans is preceded by transient aggravation of headache caused by activation of meningeal nociceptors. Pain 115, 21e28. http://dx.doi.org/10.1016/ j.pain. 2005.01.027.

Cervantes-Durán, C., Rocha-González, H.I., Granados-Soto, V., 2013. Peripheral and spinal 5-HT receptors participate in the pronociceptive and antinociceptive effects of fluoxetine in rats. Neuroscience $252,396 \mathrm{e} 409$. http://dx.doi.org/10.1016/j.neuroscience.2013.08.022.

Danese, E., Montagnana, M., Lippi, G., 2014. Platelets and migraine. Thromb. Res. $134,17 e 22$. http://dx.doi.org/10.1016/j.thromres. 2014.03.055.

Donaldson, C., Boers, P.M., Hoskin, K.L., Zagami, A.S., Lambert, G.A., 2002. The role of 5-HT1B and 5-HT1D receptors in the selective inhibitory effect of naratriptan on trigeminovascular neurons. Neuropharmacology 42 , $374 \mathrm{e} 385$.

Durham, P.L., Russo, A.F., 1999. Regulation of calcitonin gene-related peptide secretion by a serotonergic antimigraine drug. J. Neurosci. 19, 3423e3429.

Dussor, G., 2014. Serotonin, 5HT1 agonists, and migraine: new data, but old ques- tions still not answered. Curr. Opin. Support. Palliat. Care 8, 137e142. http:// dx.doi.org/10.1097/SPC.0000000000000044.

Ebersberger, A., Averbeck, B., Messlinger, K., Reeh, P.W., 1999. Release of substance P, calcitonin gene-related peptide and prostaglandin E2 from rat dura mater encephali following electrical and chemical stimulation in vitro. Neuroscience 89, 901eg07. 
Fabbretti, E., D'Arco, M., Fabbro, A., Simonetti, M., Nistri, A., Giniatullin, R., 2006. Delayed upregulation of ATP $\mathrm{P}_{2} \mathrm{X}_{3}$ receptors of trigeminal sensory neurons by calcitonin gene-related peptide. J. Neurosci. 26, 6163e6171. http://dx.doi.org/ 10.1523/JNEUROSCI.0647-06.2006.

Ferrari, M.D., Odink, J., Tapparelli, C., Van Kempen, G.M., Pennings, E.J., Bruyn, G.W., 1989. Serotonin metabolism in migraine. Neurology 39, 1239 e1242.

Giniatullin, R., Nistri, A., 2013. Desensitization properties of $\mathrm{P}_{2} \mathrm{X}_{3}$ receptors shaping pain signaling. Front. Cell. Neurosci. 7, 245. http://dx.doi.org/10.3389/ fncel.2013.00245.

Giniatullin, R., Nistri, A., Fabbretti, E., 2008. Molecular mechanisms of sensitization of pain-transducing $P_{2} X_{3}$ receptors by the migraine mediators CGRP and NGF. Mol. Neurobiol. 37, 83ego. http://dx.doi.org/10.1007/s12035008-8020-5.

Goadsby, P.J., Edvinsson, L., 1993. The trigeminovascular system and migraine: studies characterizing cerebrovascular and neuropeptide changes seen in humans and cats. Ann. Neurol. 33, 48e56. http://dx.doi.org/10.1002/ ana.410330109.

Goadsby, P.J., Hoskin, K.L., 1998. Serotonin inhibits trigeminal nucleus activity evoked by craniovascular stimulation through a $5 \mathrm{HT}_{1} \mathrm{~B} / 1 \mathrm{D}$ receptor: a central action in migraine? Ann. Neurol. 43, 711e718. http://dx.doi.org/10.1002/ ana.410430605.

Green, M.G., Scarth, J., Dickenson, A., 2000. An excitatory role for 5-HT in spinal inflammatory nociceptive transmission; state-dependent actions via dorsal horn $5-\mathrm{HT}_{3}$ receptors in the anaesthetized rat. Pain 89, 81 e88. http:// dx.doi.org/10.1016/S0304-3959(00)00346-8.

Greenshaw, A.J., Silverstone, P.H., 1997. The non-antiemetic uses of serotonin 5-HT3 receptor antagonists. Clinical pharmacology and therapeutic applications. Drugs 53, 20039.

Gupta, S., Amrutkar, D.V., Mataji, A., Salmasi, H., Hay-Schmidt, A., Sheykhzade, M., Messlinger, K., Olesen, J., Jansen-Olesen, I., 2010. Evidence for CGRP re-uptake in rat dura mater encephali. Br. J. Pharmacol. 161, 1885e1898. http://dx.doi.org/10.1111/j.1476-5381.2010.01012.x.

Hamel, E., 2007. Serotonin and migraine: biology and clinical implications. Ceph- alalgia 27, 1293e1300. http://dx.doi.org/10.1111/j.1468-2982.2007.01476.x.

Harriott, A.M., Scheff, N.N., Gold, M.S., 2012. The complex actions of sumatriptan on rat dural afferents. Cephalalgia 32, 738e749. http://dx.doi.org/10.1177/ 0333102412451356.

Hautaniemi, T., Petrenko, N., Skorinkin, A., Giniatullin, R., 2012. The inhibitory action of the antimigraine nonsteroidal anti-inflammatory drug naproxen on $\mathrm{P}_{2} \mathrm{X}_{3}$ receptor-mediated responses in rat trigeminal neurons. Neuroscience 209, 32e38. http://dx.doi.org/10.1016/j.neuroscience.2012.02.023.

Hicks, G.A., Coldwell, J.R., Schindler, M., Ward, P.A.B., Jenkins, D., Lynn, P.A., Humphrey, P.P.A., Blackshaw, L.A., 2002. Excitation of rat colonic afferent fibres by $5-\mathrm{HT}(3)$ receptors. J. Physiol. 544, 861e869.

Julius, D., Basbaum, A.l., 2001. Molecular mechanisms of nociception. Nature 413, $203 e 210$. http://dx.doi.org/10.1038/35093019.

Kadir, S.N., Goodman, D.F.M., Harris, K.D., 2014. High-dimensional cluster analysis with the masked EM algorithm. Neural Comput. 26, 2379e2394. http:// dx.doi.org/10.1162/NECO_a_00661.

Kageneck, C., Nixdorf-Bergweiler, B.E., Messlinger, K., Fischer, M.J., 2014. Release of CGRP from mouse brainstem slices indicates central inhibitory effect of triptans and kynurenate. J. Headache Pain 15, 7. http://dx.doi.org/10.1186/1129-2377-15-7. 
Khasabov, S.G., Lopez-Garcia, J.A., Asghar, A.U., King, A.E., 1999. Modulation of afferent-evoked neurotransmission by $5-\mathrm{HT}_{3}$ receptors in young rat dorsal horn neurones in vitro: a putative mechanism of $5-\mathrm{HT}_{3}$ induced anti-nociception. Br. J. Pharmacol. 127, 843e852. http://dx.doi.org/10.1038/sj.bjp.0702592.

Kim, J.M., Jeong, S.W., Yang, J., Lee, S.H., Kim, W.M., Jeong, S., Bae, H.B., Yoon, M.H., Choi, J. Il, 2015. Spinal 5$H T_{1} A$, not the $5-H T_{1} B$ or $5-H T_{3}$ receptors, mediates descending serotonergic inhibition for late-phase mechanical allodynia of carrageenan-induced peripheral inflammation. Neurosci. Lett. 600, 91e97. http://dx.doi.org/10.1016/j.neulet.2015.05.058.

Kim, Y.S., Chu, Y., Han, L., Li, M., Li, Z., Lavinka, P.C., Sun, S., Tang, Z., Park, K., Caterina, M.J., Ren, K., Dubner, R., Wei, F., Dong, $X ., 2014$. Central terminal sensitization of TRPV 1 by descending serotonergic facilitation modulates chronic pain. Neuron 81, 873e887. http://dx.doi.org/10.1016/j.neuron.2013.12.011.

Koo, J.-W., Balaban, C., 2006. Serotonin-induced plasma extravasation in the murine inner ear: possible mechanism of migraine-associated inner ear dysfunction. Cephalalgia 26, 1310e1319. http://dx.doi.org/10.1111/j.1468-2982.2006.01208.x.

Lambert, G.A., Donaldson, C., Hoskin, K.L., Boers, P.M., Zagami, A.S., 2004. Dilatation induced by 5-HT in the middle meningeal artery of the anaesthetised cat. Naunyn. Schmiedeb. Arch. Pharmacol. 369, 591e601. http://dx.doi.org/10.1007/ s00210-004-0935-4.

Lance, J.W., Anthony, M., Hinterberger, H., 1967. The control of cranial arteries by humoral mechanisms and its relation to the migraine syndrome. Headache J. Head. Face Pain 7, 93e102. http://dx.doi.org/10.1111/j.15264610.1967.hedo703134.x.

Levy, D., 2009. Migraine pain, meningeal inflammation, and mast cells. Curr. Pain Headache Rep. 13, 237 e240. http://dx.doi.org/10.1007/s11916-009-0040-y.

Levy, D., Burstein, R., Kainz, V., Jakubowski, M., Strassman, A.M., 2007. Mast cell degranulation activates a pain pathway underlying migraine headache. Pain 130, 166e176. http://dx.doi.org/10.1016/j.pain.2007.03.012.

Lukács, M., Haanes, K.A., Majla'th, Z., Tajti, J., Ve'csei, L., Warfvinge, K., Edvinsson, L., 2015. Dural administration of inflammatory soup or Complete Freund's Adjuvant induces activation and inflammatory response in the rat trigeminal ganglion. J. Headache Pain 16, 564. http://dx.doi.org/10.1186/s10194-015-0564-y.

Markowitz, S., Saito, K., Moskowitz, M.A., 1987. Neurogenically mediated leakage of plasma protein occurs from blood vessels in dura mater but not brain. J. Neurosci. 7, 4129e4136.

Martin, G.R., Eglen, R.M., Hamblin, M.W., Hoyer, D., Yocca, F., 1998. The structure and signalling properties of 5HT receptors: an endless diversity? Trends Pharmacol. Sci. 19, 2 e4.

Messlinger, K., 2009. Migraine: where and how does the pain originate? Exp. brain Res. 196, 179 e193. http://dx.doi.org/10.1007/s00221-009-1756-y.

Niesler, B., 2011. 5-HT(3) receptors: potential of individual isoforms for personalised therapy. Curr. Opin. Pharmacol. 11, 81e86. http://dx.doi.org/10.1016/ j.coph.2011.01.011.

Oatway, M.A., Chen, Y., Weaver, L.C., 2004. The 5-HT3 receptor facilitates at-level mechanical allodynia following spinal cord injury. Pain 110, 259e268. http:// dx.doi.org/10.1016/j.pain.2004.03.040.

Olesen, J., Burstein, R., Ashina, M., Tfelt-Hansen, P., 2009. Origin of pain in migraine: evidence for peripheral sensitisation. Lancet. Neurol. 8, 679e69o. http:// dx.doi.org/10.1016/S1474-4422(09)70090-0.

Oshinsky, M.L., Gomonchareonsiri, S., 2007. Episodic dural stimulation in awake rats: a model for recurrent headache. Headache 47, 1026e1036. http:// dx.doi.org/10.1111/j.1526-4610.2007.00871.x.

Panconesi, A., 2008. Serotonin and migraine: a reconsideration of the central theory. J. Headache Pain 9, $267 e 276$. http://dx.doi.org/10.1007/s10194-008-0058- 2.

INSTITUTO DE INVESTIIGAÇÃO E INOVAÇÃO EM SAÚDE UNIVERSIDADE DO PORTO

Rua Alfredo Allen, 208 4200-135 Porto Portugal +351220408800 
Pinto, V., Derkach, V.A., Safronov, B.V., 2008. Role of TTX-sensitive and TTX-resistant sodium channels in Adeltaand C-fiber conduction and synaptic transmission. J. Neurophysiol. 99, $617 \mathrm{e} 628$. http://dx.doi.org/10.1152/jn.00944.2007.

Pinto, V., Szucs, P., Lima, D., Safronov, B.V., 2010. Multisegmental A\{delta\}- and C- fiber input to neurons in lamina I and the lateral spinal nucleus. J. Neurosci. 30, 2384e2395. http://dx.doi.org/10.1523/JNEUROSCl.344509.2010.

Rondé, P., Nichols, R.A., 1998. High calcium permeability of serotonin 5-HT3 receptors on presynaptic nerve terminals from rat striatum. J. Neurochem. 70, 1094e1103.

Rudomin, P., Schmidt, R.F., 1999. Presynaptic inhibition in the vertebrate spinal cord revisited. Exp. Brain Res. 129, 1e37. http://dx.doi.org/10.1007/s002210050933.

Safronov, B.V., Pinto, V., Derkach, V.A., 2007. High-resolution single-cell imaging for functional studies in the whole brain and spinal cord and thick tissue blocks using light-emitting diode illumination. J. Neurosci. Methods 164, 292e298. http://dx.doi.org/10.1016/j.jneumeth.2007.05.010.

Sagalajev, B., Bourbia, N., Beloushko, E., Wei, H., Pertovaara, A., 2015. Bidirectional amygdaloid control of neuropathic hypersensitivity mediated by descending serotonergic pathways acting on spinal $5-\mathrm{HT}_{3}$ and $5-\mathrm{HT}_{1} \mathrm{~A}$ receptors. Behav. Brain Res. 282, 14e24. http://dx.doi.org/10.1016/j.bbr.2014.12.052.

Saxena, P.R., Ferrari, M.D., 1992. From serotonin receptor classification to the anti- migraine drug sumatriptan. Cephalalgia 12, 187e196.

Schueler, M., Messlinger, K., Dux, M., Neuhuber, W.L., De Col, R., 2013. Extracranial projections of meningeal afferents and their impact on meningeal nociception and headache. Pain 154, 1622 e1631. http://dx.doi.org/10.1016/j.pain.2013.04.040.

Segelcke, D., Messlinger, K., 2016. Putative role of $5-\mathrm{HT}_{2} \mathrm{~B}$ receptors in migraine pathophysiology. Cephalalgia. http://dx.doi.org/10.1177/0333102416646760.

Simonetti, M., Fabbro, A., D'Arco, M., Zweyer, M., Nistri, A., Giniatullin, R., Fabbretti, E., 2006. Comparison of P2X and TRPV 1 receptors in ganglia or primary culture of trigeminal neurons and their modulation by NGF or serotonin. Mol. Pain 2, 11. http://dx.doi.org/10.1186/1744-8069-2-11.

Simonetti, M., Giniatullin, R., Fabbretti, E., 2008. Mechanisms mediating the enhanced gene transcription of $\mathrm{P}_{2} \mathrm{X}_{3}$ receptor by calcitonin gene-related peptide in trigeminal sensory neurons. J. Biol. Chem. 283, 18743e18752. http:// dx.doi.org/10.1074/jbc.M800296200.

Strassman, A.M., Raymond, S.A., Burstein, R., 1996. Sensitization of meningeal sensory neurons and the origin of headaches. Nature 384, 560e564. http:// dx.doi.org/10.1038/38456oao.

Sufka, K.J., Schomburg, F.M., Giordano, J., 1992. Receptor mediation of 5-HT-induced inflammation and nociception in rats. Pharmacol. Biochem. Behav. 41, 53e56.

Szucs, P., Pinto, V., Safronov, B.V., 2009. Advanced technique of infrared LED imaging of unstained cells and intracellular structures in isolated spinal cord, brainstem, ganglia and cerebellum. J. Neurosci. Methods 177, 36ge380. http://dx.doi.org/10.1016/j.jneumeth.2008.10.024.

Taffi, R., Vignini, A., Lanciotti, C., Luconi, R., Nanetti, L., Mazzanti, L., Provinciali, L., Silvestrini, M., Bartolini, M., 2005. Platelet membrane fluidity and peroxynitrite levels in migraine patients during headache-free periods. Cephalalgia 25, 353e358. http://dx.doi.org/10.1111/j.1468-2982.2004.00863.x.

Thalakoti, S., Patil, V.V., Damodaram, S., Vause, C.V., Langford, L.E., Freeman, S.E., Durham, P.L., 2007. Neuronglia signaling in trigeminal ganglion: implications for migraine pathology. Headache 47. http://dx.doi.org/10.1111/j.1526-4610.2007.00854.x, 1008e1023e5. 
Tong, C.-K., MacDermott, A.B., 2014. Synaptic GluN2A and GluN2B containing NMDA receptors within the superficial dorsal horn activated following primary afferent stimulation. J. Neurosci. 34, 10808e10820. http://dx.doi.org/10.1523/ JNEUROSCl.0145-14.2014.

Tore, F., Tuncel, N., 2011. Anatomical and functional relationships between sensory nerves and mast cells. Antiinflamm. Antiallergy. Agents Med. Chem. 10, 10e17. http://dx.doi.org/10.2174/187152111794863736.

Vang, H., Chung, G., Kim, H.Y., Park, S.-B., Jung, S.J., Kim, J.-S., Oh, S.B., 2012. Neurochemical properties of dental primary afferent neurons. Exp. Neurobiol. 21, 68e74. http://dx.doi.org/10.5607/en.2012.21.2.68.

Viguier, F., Michot, B., Hamon, M., Bourgoin, S., 2013. Multiple roles of serotonin in pain control mechanismseimplications of $5-\mathrm{HT} 7$ and other $5-\mathrm{HT}$ receptor types. Eur. J. Pharmacol. 716, 8e16. http://dx.doi.org/10.1016/j.ejphar.2013.01.074.

Wild, V., Messlinger, K., Fischer, M.J.M., 2015. Hydrogen sulfide determines HNO- induced stimulation of trigeminal afferents. Neurosci. Lett. 602, 104e109. http://dx.doi.org/10.1016/j.neulet.2015.06.056.

Williamson, D.J., Shepheard, S.L., Hill, R.G., Hargreaves, R.J., 1997. The novel anti- migraine agent rizatriptan inhibits neurogenic dural vasodilation and extrava- sation. Eur. J. Pharmacol. 328, 61e64. http://dx.doi.org/10.1016/S0014-2999(97) 83028-2.

Yegutkin, G.G., Guerrero-Toro, C., Kilinc, E., Koroleva, K., Ishchenko, Y., Abushik, P., Giniatullina, R., Fayuk, D., Giniatullin, R., 2016. Nucleotide homeostasis and purinergic nociceptive signaling in rat meninges in migraine-like conditions. Purinergic Signal 12, 561e574. http://dx.doi.org/10.1007/s11302-016-9521-8.

Zakharov, A., Vitale, C., Kilinc, E., Koroleva, K., Fayuk, D., Shelukhina, I., Naumenko, N., Skorinkin, A., Khazipov, R., Giniatullin, R., 2015. Hunting for origins of migraine pain: cluster analysis of spontaneous and capsaicin-induced firing in meningeal trigeminal nerve fibers. Front. Cell. Neurosci. 9 http:// dx.doi.org/10.3389/fncel.2015.00287.

Zeitz, K.P., Guy, N., Malmberg, A.B., Dirajlal, S., Martin, W.J., Sun, L., Bonhaus, D.W., Stucky, C.L., Julius, D., Basbaum, A.I., 2002. The $5-\mathrm{HT}_{3}$ subtype of serotonin receptor contributes to nociceptive processing via a novel subset of myelinated and unmyelinated nociceptors. J. Neurosci. 22, 1010e1019.

Zhang, X.-F., Zhu, C.Z., Thimmapaya, R., Choi, W.S., Honore, P., Scott, V.E., Kroeger, P.E., Sullivan, J.P., Faltynek, C.R., Gopalakrishnan, M., Shieh, C.-C., 2004. Differential action potentials and firing patterns in injured and uninjured small dorsal root ganglion neurons after nerve injury. Brain Res. 1009, $147 \mathrm{e} 158$. http://dx.doi.org/10.1016/j.brainres.2004.02.057.

Zhang, Y., Zhao, S., Rodriguez, E., Takatoh, J., Han, B.-X., Zhou, X., Wang, F., 2015. Identifying local and descending inputs for primary sensory neurons. J. Clin. Invest 125, 3782e3794. http://dx.doi.org/10.1172/JCl81156 